Canadian

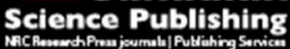

Environmental Reviews Dossiers environnement

\title{
Economic and Ecological Trade-Off Analysis of Forest Ecosystems: Options for Boreal Forests
}

\begin{tabular}{|r|l|}
\hline Journal: & Environmental Reviews \\
\hline Manuscript ID & er-2015-0090.R2 \\
\hline Manuscript Type: & Review \\
\hline Date Submitted by the Author: & 11 -May-2016 \\
\hline Complete List of Authors: & $\begin{array}{l}\text { Chen, Si; Lakehead University, Natural Resources Management } \\
\text { Shahi, Chander; Lakehead University, Natural Resources Management } \\
\text { Chen, Han; Lakehead University, Natural Resources Management }\end{array}$ \\
\hline Keyword: & $\begin{array}{l}\text { boreal forest, ecological functions, economic gains, ecosystem services, } \\
\text { multi-objective optimization, trade-offs }\end{array}$ \\
\hline
\end{tabular}


1 Economic and Ecological Trade-Off Analysis of Forest Ecosystems: Options

for Boreal Forests

\author{
Si Chen ${ }^{1}$, Chander Shahi ${ }^{1}$, and Han Y.H. Chen ${ }^{1}$
}

$4 \quad{ }^{1}$ Faculty of Natural Resources Management, Lakehead University, 955 Oliver Road, Thunder

6 Corresponding author: e-mail: $\underline{\text { schen13@lakeheadu.ca }}$

7 Phone: (807) 343-8796

$8 \quad$ Fax: (807) 343-8116

9 Word count: 6,766 (text only, excluding abstract, acknowledgements, references) 


\section{Abstract}

Intensive forest management practices for production forestry can potentially impact the

12 sustainability of ecological functions and associated forest ecosystem services. Understanding

13 the trade-offs between economic gains and ecological losses is critical for the sustainable

14 management of forest resources. However, economic and ecological trade-offs are typically

15 uncertain, vary at temporal and spatial scales, and are difficult to measure. Moreover, the

16 methods used to quantify economic and ecological trade-offs might have conflicting priorities.

17 We reviewed the most current published literature related to trade-off analysis between economic 18 gains and sustainability of forest ecosystem functions and associated services, and found that

19 most economic and ecological trade-offs studies were conducted in tropical and temperate

20 forests, with few having their focus on boreal forests. Analytical methods of these published

21 studies included monetary valuation, biophysical models, optimization programming, production

22 possibility frontier and multi-objective optimization. This review has identified the knowledge

23 gaps in the understanding and measurement of the economic and ecological trade-offs for the

24 sustainable management of boreal forests. While it remains uncertain how economic activities

25 might best maintain and support multiple ecological functions and associated services in the

26 boreal forests, which are susceptible to climate change and disturbances, we propose the use of

27 optimization methods employing multiple objectives. For any tool to provide sustainable and

28 optimal forest management solutions, we propose that appropriate and robust data must be

29 collected and analyzed.

30 Keywords: boreal forest, ecological functions, economic gains, ecosystem services, multi-

31 objective optimization, trade-offs 


\section{Introduction}

Human society is inextricably linked to forest ecosystems, which provide an extensive array of functions and services that are of increasing value for societal and economic prosperity (Millennium Ecosystem Assessment 2005). Ecological functions include any natural processes that control energy flux, nutrients, and organic matter within forest ecosystems (Cardinale et al. 2012). These ecological functions provide four primary categories of ecosystem services to humanity, which include: (i) production functions and provisioning services (e.g., renewable raw materials such as timber, fiber, pharmaceuticals, food, bioenergy, and non-renewable energy resources), (ii) habitat functions and supporting services (e.g., supporting biodiversity, nutrient cycling, and primary productivity), (iii) regulation functions and regulating services (e.g., pollination, climate regulation, and carbon sequestration), and (iv) information functions and cultural services (e.g., recreational and aesthetic values) (de Groot et al. 2002; Millennium Ecosystem Assessment 2005). The overall value of forest ecosystems encompasses both extractive/priceable services, and non-extractive/unpriceable services (Zhang and Pearse 2012).

However, the economic gains garnered from forest ecosystems are only provided through production functions and provisioning services, which may be exchanged for currency in the markets. With increasing anthropogenic pressures that impinge on forests, intensive forest management practices that aim to maximize economic gains have impacted the sustainability of forest ecosystems and their ecological processes (Vitousek 1997; Costanza et al. 2014).

The valuation of ecological functions and services of forest ecosystems is a difficult and controversial task, where economists have often been criticized for attempting to affix a price tag on nature (Heal 2000; Admiraal et al. 2013; Adams 2014). However, the trade-offs in the allocation of resources to protect forest ecosystems might only be understood through economic 
55 decisions that are based on societal values. The perceptions of ecologists may be completely

56 different due to ineffective policies or institutions (Femia et al. 2001). Under the imbalanced

57 provision of economic and ecological forest ecosystem valuation, the cost of ecological losses

58 through interventions into natural processes is the price that society must pay in return for the

59 economic gains (Rodriguez et al. 2006). For example, the production of industrial grade wood

60 from the boreal forests of Canada, has led to the degradation of ecological functions and services

61 in boreal zones (Brandt et al. 2013). Economic and ecological trade-offs are typically uncertain

62 and difficult to reconcile with an increasing emphasis on intensive forest management across a

63 wide range of temporal and spatial scales (Rodriguez et al. 2006). Therefore, there is a need to

64 explore the trade-offs between suitable options for intensive forest management that may satisfy

65 economic gains, while simultaneously minimizing losses in ecological functions and associated

66 services from forest ecosystems (DeFries et al. 2004; Steffan-Dewenter et al. 2007).

67 In the boreal forests of Canada, forest management practices are prescribed to efficiently

68 and effectively maintain and enhance the long term health of forest ecosystems (Burton et al.

69 2006). For example, the two principles under the Crown Forest Sustainability Act (CFSA, 1994)

70 that assist in sustainably managing forests to meet the environmental, economic, and social

71 requirements for present and future generations include: (i) conservation of ecological functions

72 and biological diversity, and (ii) emulating natural disturbances, while minimizing adverse

73 impacts on forest valuation. In order to safeguard these two principles, the response of a forest

74 ecosystem to forest management practices (primarily harvesting) must be quantified in order to

75 ensure that species diversity, population trends, community organization, and functional

76 properties are in alignment with typical responses to natural disturbances (e.g., fires, drought,

77 severe storms, and insect attacks) (Attiwill 1994; Landres et al. 1999; Parkins and MacKendrick 
2007; Venier et al. 2014). Forest management options for Canadian boreal forests include two primary biomass harvesting methods; stem-only harvesting for sawlogs and pulp logs, and fulltree harvesting for maximizing biomass extraction from the forests, which may have detrimental effects in terms of the sustainability of ecological functions and associated services (Canadian Council of Forest Ministers 2005; Maynard et al. 2014). However, our understanding of the economic and ecological trade-offs of these forest management practices remain limited. An improved understanding of the trade-offs between economic gains and ecological functions at various spatial and temporal scales may assist in decision-making, and strengthening policy formulation, for forest management practices that incorporate multiple objectives (Nelson et al. 2009; McShane et al. 2011). However, to the best of our knowledge, there is no systematic review that provides a comprehensive picture of economic and ecological trade-off studies across the globe, or the methods used thereof, for arriving at these trade-off comparisons in forest ecosystems. This knowledge gap impedes the ability of forest managers and researchers to evaluate the consequences of different forest management scenarios. Trade-off analysis will facilitate the identification of optimum forest management options with efficient resource-use and renewal patterns that maximize economic gains, while minimizing ecological losses. Therefore, the rationale behind this paper was to review the published literature over the last twenty years that sought to measure and explain the economic and ecological trade-offs of forest management options with conflicting priorities. Specifically, our objectives were: (i) to assess the current state of economic and ecological trade-off studies that have been conducted in forest ecosystems, (ii) to examine and classify the methods used in these studies, and (iii) to explore suitable options for forest management under conflicting priorities in boreal forests. 


\section{Approach}

\subsection{Definition of terms}

102

103

In this review, economic gains are defined as the profits or discounted constant dollar values from total or partial outputs of merchantable forest resource extraction. Economic gains should be quantified in monetary units, coming mainly from production functions and provisioning services, such as timber and non-timber products that could be exchanged in the markets. In contrast, ecological losses include a wide range of ecological functions and services provided by forest ecosystems that cannot be exchanged in the markets.

\subsection{Literature selection}

The online search engine, Thomson Reuters (ISI) Web of Knowledge (2016), was employed to search published (1994 - 2016) peer-reviewed economic and ecological trade-off journal articles. Different combinations of search terms and key words, such as "economic gain", “economic benefit", “economic development”, “economic return”, “ecological function”, “ecosystem service", "trade*”, and "trade-off", were employed to ensure that the searches included all relevant economic and ecological trade-off studies of forest ecosystems. The literature cited by the retrieved articles were also consulted in order to seek additional relevant articles. From the search, we extracted 101 original journal articles that focused on economic and ecological trade-off analyses in forest ecosystems. Subsequently, the selected peer-reviewed articles were examined in depth to investigate the methods used for economic and ecological trade-off comparisons, and the eligible peer-reviewed articles were categorized based on these methods. 
121

122

123

124

125

126

127

128

129

130

131

132

133

134

135

136

137

138

139

140

141

142

\section{Current state of trade-off studies}

The spatial distribution of the studies, using economic and ecological comparison methods, encompassed an extensive global reach (Fig. 1), albeit there was a notable absence of such studies in Northern Eurasia, the Middle East, and Africa. Worldwide, economic and ecological trade-off studies were heavily skewed toward tropical and temperate forests, accounting for $74.3 \%$ of the peer-reviewed articles, whereas only $25.7 \%$ of the articles investigated boreal forests. The top three countries included the United States (27 articles), Finland (12 articles), and Indonesia (8 articles), which represented nearly half of the total peerreviewed articles. Moreover, the majority of the economic and ecological comparison studies focused on biodiversity and habitat diversity (42.9\%). Additional ecological functions and ecosystem services in the studies encompassed carbon stocks and sequestration $(29.2 \%)$, water regulation and supply (7.1\%), cultural services $(6.5 \%)$, erosion protection and soil fertility $(5.8 \%)$, disturbance regulation $(2.6 \%)$, pollination services $(2.6 \%)$, waste regulation $(1.3 \%)$, oxygen production (1.3\%), and surface albedo (0.7\%) (Fig. 2).

\section{Economic and ecological trade-off methods}

Based on the methods classification criteria, both monetary and non-monetary techniques were employed for economic and ecological trade-off methods. Monetary valuation methods analyze trade-offs by comparing economic gains with ecological goals as net present values based on cost-benefit evaluations. Monetary valuation methods have been commonly employed for tropical agroforests, with only a single study found for boreal forests (Ahtikoski et al. 2011). However, non-monetary modeling techniques for ecological losses $(92.1 \%$ of the studies $)$ formed the majority of trade-off methods, including biophysical models (37.6\%) and operations research 
143 models (62.4\%); a modeling technique that utilizes advanced analytical optimization to facilitate 144 improved decisions. Three categories of operations research models have been commonly used 145 for trade-off analyses, including optimization programming (46.6\%), production possibility 146 frontier (32.7\%), and multi-objective optimization (20.7\%) (Winston and Goldberg 2004) (Fig. $1473)$.

\subsection{Monetary valuation}

Monetary valuation is an interdisciplinary collaboration, where economists attempt to 150 evaluate the dollar value of ecological functions and ecosystem services, which are otherwise unpriced in the market (Farley 2008). A wide range of calibration tools have been developed for monetary valuation, which may be divided into the following three categories (Gatto and De Leo 2000; Farber et al. 2006; Turner et al. 2016): (i) replacement and restoration costs that use

154 market prices of man-made treatment systems to replace or restore the impacted ecological 155 functions and ecosystem services; (ii) stated preference methods (i.e., contingent valuation 156 method), which attempts to build pseudo markets through hypothetical choices that ask 157 consumers to state their willingness to pay for ecological functions and ecosystem services, 158 which are not traded in markets; (iii) revealed preference methods that are used to evaluate 159 market values for ecological functions and ecosystem services based upon the behaviors or 160 attitudes of consumers, including travel cost methods and hedonic price methods. The price or 161 marginal cost (i.e., change in total cost created by one unit increase in quantity) of ecological 162 functions and ecosystem services is measured in order to understand the trade-offs between 163 economic gains and tree species diversity (Bottazzi et al. 2014), carbon stock and sequestration 164 (Naidoo and Ricketts 2006; Olschewski and Benitez 2010; Olschewski et al. 2010; Bottazzi et al. 
165 2014), pollination services (Ricketts et al. 2004; Viglizzo and Frank 2006; Priess et al. 2007;

166 Olschewski et al. 2010), cultural services (Ahtikoski et al. 2011), biological control, erosion

167 control, soil formation, water regulation, waste treatment, gas regulation, and climate regulation

168 (Viglizzo and Frank 2006). For example, Viglizzo and Frank (2006) analyzed the economic and

169 ecological trade-offs by synthesizing more than 100 studies that priced ecosystem services using

170 a variety of monetary valuation methods across the globe (Costanza et al. 1997).

171

The application of monetary valuations enables the formulation of efficient policies for

172 forest management that have the greatest social welfare (Godoy et al. 2000; Heal 2000; de Groot

173 et al. 2012). Nevertheless, monetary valuations assigned to ecological functions and ecosystem

174 services should be treated with caution for several reasons (Bateman et al. 2013). Firstly,

175 monetary methods for pricing ecological functions and ecosystem services are unavoidably

176 uncertain (Balmford et al. 2002), resulting in dissimilar valuations contingent on various

177 stakeholders (Howe et al. 2014). Hence, diverse societies and evaluators with specific

178 sociocultural preferences, in different environments and during different time periods, may result

179 in different appraisals of ecological functions and ecosystem services (Martin-Lopez et al. 2012).

180 For instance, willingness to pay is determined by preferences that are weighted by income and

181 regional scarcity (Farley 2008; Wainger and Mazzotta 2011). Hence, forests may be highly

182 valued by a wealthy population for their aesthetic and recreational attributes, in contrast to the

183 financially challenged, who depend on the same forest resources for their subsistence. Secondly,

184 not all ecological functions and ecosystem services may be measured directly or manipulated

185 experimentally, and their economic values are not exclusive due to interactions and

186 interdependence. In general, diverse components of ecological functions and ecosystem services

187 are co-produced as bundles, which may interact synergistically or competitively (Bennett et al. 
188 189

2009; Raudsepp-Hearne et al. 2010), and the relationships are likely to be highly nonlinear, resulting in unintentional economic trade-offs (Rodriguez et al. 2006).

Despite their problems, forest policies and incentives are established through monetary trade-off analyses. The policy of payments for ecosystem services (PES) is an example (Ricketts et al. 2004; Viglizzo and Frank 2006; Olschewski et al. 2010), which serves as a critical tool for the conservation and sustainability of forest resources, and improvement of human well-being (Ferraro and Kiss 2002; Wunder 2008; Redford and Adams 2009). This involves the users of ecological functions and ecosystem services; paying those who supply them through government programmes or private sector initiatives, as a tax or user fee. PES assists consumers to intuitively understand the importance of, and be rewarded for, the protection of forest ecosystems, while governments formulate appropriate policies. However, PES is not always the correct approach for every situation, as it sometimes fails to meet the criteria of actual markets, additional taxes, regulations, and zoning laws that are required to underpin the payment scheme (Muradian et al. 2013).

Therefore, it is challenging to develop standard and widely acceptable money-metric measures for unpriced ecological functions and ecosystem services (de Groot et al. 2012; Adams 2014). Monetary valuation is better suited for managed forest ecosystems with similar site conditions, such as agroforestry ecosystems, which are closely linked with the economic interests of individuals, along with easy market access. As managed forests are intended to be utilized for harvesting, some ecological services are better evaluated by the market price of replacement and restoration costs of forests, post-harvest. However, monetary measures are difficult to apply to natural forests that are not closely linked with socioeconomic value. 


\subsection{Biophysical models}

Considering that intangible ecological services are difficult to be monetized in isolation,

212 as these typically occur over different spatial and temporal scales, an understanding of the role of

213 biophysical factors (such as light, slope, water conditions, soil texture and nutrients, climate,

214 temperature, precipitation, humidity, and altitude) are crucial in explaining ecosystem

215 components and processes for their future impacts (Redford and Adams 2009). Without

216 appropriate modeling with biophysical factors, forest management policies, incentives or

217 payment schemes that optimize the delivery of those services appear inefficient (Nelson et al.

218 2009). Biophysical models may facilitate the analysis of trade-offs imbalance due to the

219 application of land-use policies (Carreno et al. 2012), and often incorporate simulated trade-off

220 scenarios of measurable economic gains (Nelson et al. 2009; Polasky et al. 2011; Goldstein et al.

221 2012). Ecological losses in the biophysical models are expressed in monetary, proportional,

222 quantitative, or relative units.

Biophysical models have been commonly employed to study economic and ecological trade-offs in tropical and temperate forests, for both managed and unmanaged scenarios, with 225 disturbances and natural cycles, without management intervention (Duncker et al. 2012). In the

226 reviewed literature, $45.7 \%$ of the studies that used biophysical models were conducted in tropical

227 forests, primarily in agroforestry (Steffan-Dewenter et al. 2007; van Noordwijk et al. 2008;

228 Clough et al. 2011; Goldstein et al. 2012; Mulia et al. 2014; Yi et al. 2014), and 42.9\% in 229 temperate forests, while there were only $11.4 \%$ in boreal forests. Biophysical models focus on 230 balancing economic gains with biodiversity preservation (Hansen et al. 1995; Grasso 1998; Faith 231 et al. 2001; Faith and Walker 2002; Marzluff et al. 2002; van Noordwijk 2002; Williams et al. 232 2003; Chopra and Kumar 2004; Steffan-Dewenter et al. 2007; Nelson et al. 2009; Prato 2009; 
233 Mendenhall et al. 2011; Polasky et al. 2011; Carreno et al. 2012; Duncker et al. 2012; Gret-

234 Regamey et al. 2013; Yi et al. 2014; Wood et al. 2016), carbon stocks or sequestration (Pussinen 235 et al. 2002; van Noordwijk 2002; Garcia-Gonzalo et al. 2007; Seidl et al. 2007; Seidl et al. 2008;

236 van Noordwijk et al. 2008; Nelson et al. 2009; Raudsepp-Hearne et al. 2010; Baskent et al. 2011;

237 Duncker et al. 2012; Goldstein et al. 2012; Gret-Regamey et al. 2013; Cademus et al. 2014;

238 Mulia et al. 2014; Pyorala et al. 2014; Lutz et al. 2015; Bottalico et al. 2016), water regulation 239 and supply (Nelson et al. 2009; Baskent et al. 2011; Carreno et al. 2012; Duncker et al. 2012;

240 Goldstein et al. 2012; Vidal-Legaz et al. 2013; Cademus et al. 2014; Gissi et al. 2016), erosion 241 protection and soil fertility (Steffan-Dewenter et al. 2007; Nelson et al. 2009; Raudsepp-Hearne

242 et al. 2010; Carreno et al. 2012; Gissi et al. 2016; Wood et al. 2016), cultural services

243 (Raudsepp-Hearne et al. 2010; Gret-Regamey et al. 2013), disturbance regulation (Gret-

244 Regamey et al. 2013; Maroschek et al. 2015), oxygen production (Baskent et al. 2011), and 245 surface albedo (Lutz et al. 2015).

Although biophysical models may assist with the design of appropriate forest

247 management strategies among alternative scenarios, a major limitation of these models is

248 associated with the uncertainty of the true value of the model parameters (Vidal-Legaz et al.

249 2013). The factors and variables used in the generalized biophysical models are built mainly on

250 the assumptions of metadata and ecological theories, and are lacking in empirical evidence due

251 to the non-availability of data (Nelson et al. 2009). Biophysical models typically use simplified

252 equations with fewer factors, which are relatively easy to measure (Carreno et al. 2012), to

253 reduce the risk of multi-collinearity and auto-correlation among biophysical variables. This is

254 because it is very difficult to quantitatively assess all interdependent biophysical factors (Bennett

255 et al. 2009), and the model ignores many factors that may contribute to trade-offs (Holling and 
256 Meffe 1996; Adams 2014). Moreover, the trade-off analysis in biophysical models is derived

257 from various units (e.g., monetary, proportional, quantitative, or relative), making it problematic

258 to compare outcomes. The biophysical models, although superior to the monetary method, in

259 both estimation scope and forecasting scale, suffer from the above-mentioned constraints.

\subsection{Optimization programming}

Unlike biophysical models that offer preferred solutions among diverse scenarios, optimization programming optimizes benefits from both economic and ecological perspectives. A series of analytical problem-solving optimality techniques have been adapted from the field of operations research to study economic and ecological trade-offs for forest ecosystems. constrained within diverse environments to arrive at optimal, or near-optimal, solutions for

267 decision making, where one objective is optimized and other objectives are treated as constraints

268 (Winston and Goldberg 2004). Both economic and ecological objectives are measured through mathematical algorithms such as, linear, non-linear, dynamic, integer, and heuristic

270 programming. Linear programming, the most common and traditional optimization technique,

271 aims to achieve optimum trade-off solutions through mathematical models with linear objective

272 functions, governed by linear constrains (Hiroshima 2004). For example, linear programming 273 was employed to examine the economic-ecological trade-offs that aim at maximizing objectives

274 that are directly related to biodiversity, vegetative, or structural diversity (Holland et al. 1994;

275 Buongiorno et al. 1995; Ingram and Buongiorno 1996; Boscolo and Buongiorno 1997; Onal

276 1997; Lin and Buongiorno 1998; Mendoza et al. 2000; Juutinen and Monkkonen 2007;

277 McCarney et al. 2008), carbon stocks or sequestration (Hoen and Solberg 1994; Boscolo and 278 Buongiorno 1997; Krcmar et al. 2001; Backeus et al. 2005, 2006; Baskent et al. 2008; McCarney 
279 et al. 2008; Zubizarreta-Gerendiain et al. 2016), biophysical sustainability, such as soil nutrient

280 (Bouman et al. 1998), and oxygen production (Baskent et al. 2008). However, many real world

281 ecological and economic problems involve complex non-linear objective functions and

282 constraints that cannot be specified by linear programming techniques. As a result, non-linear

283 programming methods have also been utilized to develop forest management plans between

284 monetary returns and the maintenance of tree size and structural diversity (Buongiorno et al.

285 1994; Kant 2002).

Dynamic programming is utilized by initially breaking the problem down into multiple

287

288

289

290

291

292

293

294

295

296

297

298

299

300

301

time steps and simpler sub-problems that describe a sequential process, and then integrating the sub-solutions together to attain a precise solution (Stirn 2006). For example, dynamic

programming methods provide an optimal balance with the quantification of trade-offs between economic gains, biodiversity conservation or carbon sequestration for a series of time steps in a multi-stage decision-making process (Doherty et al. 1999; Spring et al. 2005; Yousefpour and Hanewinkel 2009). Similarly, mixed integer programming, an optimization approach in which some or all variables are restricted to be integers (Wolsey 1998), has been used to incorporate an optimal balance between economic revenue and biodiversity (Rose and Chapman 2003; Ohman et al. 2011). Nevertheless, it is cumbersome to solve large trade-off problems with many integer variables and alternatives by considering all possible combinations of integer variables using mixed integer programming (Arthaud and Rose 1996), and for very complex economicecological trade-off problems, an exhaustive search is sometimes impractical due to the size of the problem. Heuristic programming then offers a set of approximations and global optimal solutions, rather than an exact solution (Murray and Church 1995). Heuristic programming has illustrated satisfactory solutions in trade-off analyses between economic timber harvests and 
302 wildlife conservation goals (Bettinger et al. 1997; Bettinger et al. 1998; Bettinger et al. 1999;

303 Bettinger et al. 2003). However, the main drawback of heuristics is that they cannot guarantee 304 optimality, and it is difficult to evaluate the suitability of an approximate solution (Nalle et al. 305 2004).

Although, optimization programming methods may be used to develop optimal

307 management plans ranging from small to large scale, these methods lack the ability to examine trade-offs among multiple objectives simultaneously. The non-availability of data coupled with the complexity of market and environmental constraints have restricted the use of mathematical models that incorporate optimization programming. In addition, optimization programming methods focus on the selection of an exact solution, or an approximate global solution, thereby ignoring the opportunity to realize a series of indifferent optimum solutions with different 313 objectives.

\subsection{Production possibility frontier} optimization approach to arrive at a series of optimum management solutions. PPF is a graphic

317 integration of optimization techniques that typically illustrates the trade-offs for two opposing 318 objectives through an efficiency frontier, which is a state of resource allocation where it is not 319 possible to make one objective better off without making another objective worse off (Calkin et al. 2002). The efficiency frontier indicates the cost-effective combinations of the two objectives

321 with efficient (on the frontier), inefficient (below the frontier), and infeasible (above the frontier)

322 solutions. The slope of the PPF is the marginal opportunity cost of the attainment of one 323 objective at the expense of another (Lichtenstein and Montgomery 2003). In PPF, economic 324 models are used to assess economic gains, whereas biophysical models, optimization 
325 programming, or monetary valuation methods are used to assess losses of ecological functions 326 and associated services. For instance, PPF integrates heuristic programming to trace out an

327 efficient trade-off frontier between economic and biodiversity objectives with a set of

328 approximate solutions (Calkin et al. 2002; Lichtenstein and Montgomery 2003; Nalle et al. 2004;

329 Polasky et al. 2005; Tikkanen et al. 2007; Polasky et al. 2008).

330 The production possibility frontier has been used to compare the trade-offs between 331 timber values and biodiversity, specifically faunal diversity in tropical and temperate forests

332 (Montgomery et al. 1994; Montgomery 1995; Arthaud and Rose 1996; Boscolo et al. 1997;

333 Boscolo and Buongiorno 2000; Rohweder et al. 2000; Calkin et al. 2002; Boscolo and Vincent

334 2003; Lichtenstein and Montgomery 2003; Nalle et al. 2004; Perfecto et al. 2005; Polasky et al.

335 2005; Polasky et al. 2008), and timber values and carbon objectives in tropical forests (Boscolo

336 et al. 1997; Boscolo and Buongiorno 2000; Boscolo and Vincent 2003). For example, Polasky et

337 al. (2008) analyzed trade-offs of the biological and economic consequences of alternative forest 338 management at a landscape level by developing a spatially explicit biological model, which 339 incorporated habitat preferences, area requirements, and the dispersal ability for terrestrial 340 vertebrate species, and a spatially explicit economic model, which integrated site characteristics 341 and locations for economic prediction. Incorporating a heuristic approach, PPF identified 342 efficient forest management alternatives that maximized biodiversity conservation for given 343 levels of economic returns on the production set of feasible combinations, and vice versa. Only 344 six PPF studies have been conducted in the boreal forests (Kangas and Pukkala 1996; Carlsson 345 1999; Andersson et al. 2006; Hurme et al. 2007; Tikkanen et al. 2007; Hauer et al. 2010). The 346 limitation of using PPF is that it only optimizes two objectives in the provision of a two- 
347 dimensional efficiency frontier, whereas actual forest management challenges often include 348 multiple conflicting objectives (Calkin et al. 2002).

\subsection{Multi-objective optimization}

In practice, there are multiple objectives to be optimized simultaneously with one objective, possibly influencing one or more other objectives in real world forest management scenarios (Probert et al. 2011). Multi-objective optimization, belonging to the wide spectrum of operations research models (Kangas and Kangas 2005), are a collection of optimization methods

354 (multi-criteria decision making, Pareto optimization, goal programming, and compromise programming), which can deal with multiple and conflicting objectives for decision-making

356 (Mendoza and Martins 2006). sequestration, ground water recharge, and cultural services are often weighted with different percentages based on their utility for the user (Faith et al. 1996; Seely et al. 2004; Furstenau et al. 2007; Briceno-Elizondo et al. 2008; Schwenk et al. 2012; Cordingley et al. 2016). For instance,

361 Schwenk et al. (2012) implemented a multi-criteria decision method to analyze the trade-offs 362 among three objectives, carbon storage, timber production, and biodiversity. However, the 363 choice of standardized criteria and the hierarchical level of objectives directly influenced the 364 evaluation results (Furstenau et al. 2007). Pareto optimization is an interdisciplinary multicriteria trade-off analysis that uses a simulation-based optimization approach to arrive at efficient options among multiple objectives (Seppelt et al. 2013). This optimization method generates an

367 efficient Pareto frontier where it is not possible to enhance one objective without another, with a 368 set of potentially feasible "win-win" combinations. We found very few studies that utilized 369 Pareto optimization to analyze ecological and economic trade-offs (Zhou and Gong 2005; 
370 Monkkonen et al. 2014; Garcia-Gonzalo et al. 2015; Trivino et al. 2015). For example,

371 Monkkonen et al. (2014) conducted a trade-off study between economic gains and biodiversity

372 from four tree species and six vertebrate species, using Pareto optimization in a Finnish boreal

373 forest. This group generated Pareto optimal solutions through Pareto frontier, and the results

374 demonstrated that it is possible to achieve "win-win" scenarios with the optimization of both

375 economic and biodiversity objectives. The other two branches of multi-objective optimization

376 include goal programming and compromise programming. The single most important objective

377 is optimized in goal programming, while other objectives are transferred into constraints (Díaz-

378 Balteiro and Romero 2003). Whereas in compromise programming the multi-objective

379 optimization problem is solved as a single aggregate objective function formed by combining

380 differently weighted objectives (Krcmar et al. 2005).

381

Nevertheless, there are very few studies that have used multi-objective optimization

382 methods; this technique provides many advantages over other techniques for multi-objective

383 problem solving in forest management. First, there is no requirement to ascribe monetary value

384 to ecological functions and ecosystem services, which may be inaccurate and imperfect. Second,

385 this technique is a multi-dimensional visualization of trade-offs among multiple objectives,

386 spatially or temporally. Third, it provides a series of satisfactory optimal solutions to planners by

387 presenting all feasible scenarios under specific constraints (Seppelt et al. 2011). Fourth, by

388 tracing out efficient optimal solutions, this technique also assists with mitigating trade-offs

389 through optimization, and facilitates arriving at more efficient forest management decisions.

\section{Economic and ecological trade-off studies in boreal forests}

Although the boreal biome accounts for $30 \%$ of global terrestrial phytomass, and is one

392 of the world's most important bio-geoclimatic areas (Brandt 2009), it remains the least studied 
393 biome. We found only 26 studies (19 for Fennoscandia, 7 for Canada) that conducted the 394 economic and ecological trade-off analysis in boreal forests (Table 1). Nine studies (six in 395 Fennoscandia, three in Canada) used linear, non-linear, and mixed-integer programming 396 techniques to optimize both spatial habitat suitability and timber revenues for long-term forest 397 management (Hoen and Solberg 1994; Krcmar et al. 2001; Kant 2002; Backeus et al. 2005, 398 2006; Juutinen and Monkkonen 2007; McCarney et al. 2008; Ohman et al. 2011; Zubizarreta399 Gerendiain et al. 2016). Six studies (five in Fennoscandia, one in Canada) used PPF to optimize 400 biodiversity and economic gains, and illustrated that optimum forest management regimes did 401 exist that led to greater timber production with minimum biodiversity losses among several 402 alternatives (Kangas and Pukkala 1996; Carlsson 1999; Andersson et al. 2006; Hurme et al. 403 2007; Tikkanen et al. 2007; Hauer et al. 2010). Four studies (three in Finland, one in Canada) 404 applied biophysical models based on simulations to analyze the economic and ecological trade405 offs involving carbon objectives, cultural services, soil retention, and soil fertility (Pussinen et al. 406 2002; Garcia-Gonzalo et al. 2007; Raudsepp-Hearne et al. 2010; Pyorala et al. 2014). Pareto 407 optimization has also been used to examine the economic and ecological trade-offs among four 408 objectives (timber production, preservation of biodiversity, reindeer grazing, and recreation) in 409 Sweden (Zhou and Gong 2005), and multiple biodiversity or carbon objectives in Finland 410 (Monkkonen et al. 2014; Trivino et al. 2015). Two studies from Finland and Canada utilized 411 multi-criteria decision making by giving partial weights to economic gains, biodiversity, and 412 carbon sequestration, and the analysis showed that forest management options may be modified 413 by taking advantage of multiple constraints (Seely et al. 2004; Briceno-Elizondo et al. 2008). A 414 multi-objective study in Canada utilized compromise programming to analyze carbon uptake, 415 maintenance of structural diversity, and economic returns to reveal the most optimal strategy that 
416 performed better in the attainment of specific objectives (Krcmar et al. 2005). Monetary

417 valuation techniques have also been employed in the boreal forest to offset the economic losses

418 due to intensive forest management practices by increasing the number of tourists (Ahtikoski et 419 al. 2011).

Several factors may have led to this publication bias in the area of economic and

421 ecological trade-off in the boreal forests in contrast to the tropical and temperate forests. First,

422 negative effects related to the loss of ecological functions and services tend to occur much earlier

423 in tropical and temperate forests, than those in boreal forests. Second, ecological functions and

424 ecosystem services in countries populated by boreal forests remain undervalued, poorly

425 understood, and typically external to the markets because of the abundance of resources (Lee

426 2004). Finally, economic and ecological trade-off studies are of the least importance for boreal

427 forests, as it is believed that comprehensive environmental regulations and laws are in place to

428 enhance the long-term sustainability of forest ecosystems in boreal residing countries that

429 mitigate economic and ecological conflicts (Chapin et al. 2006).

4306 The need for trade-off studies in boreal forests

$431 \quad 6.1$ Trade-off analysis under the impact of climate change

432 Climate change is expected to have the largest influence on boreal forests because of the

433 high rate of global warming in high latitudes over the next century (Diffenbaugh and Field

434 2013). Changing temperatures, moisture, nutrient availability, and atmospheric $\mathrm{CO}_{2}$ may alter

435 important ecological functions and ecosystem services, which will impact the boreal biome

436 (Kirilenko and Sedjo 2007). For example, climate change impacts may lead to substantial

437 increases in plant mortality (Allen et al. 2010; Luo and Chen 2015), changes in net biomass (Ma 
438

439

440

441

442

443

444

445

446

447

448

449

450

451

452

453

454

455

456

457

458

459

460

et al. 2012; Chen and Luo 2015) and biodiversity (Chapin et al. 2000; Sala et al. 2000; Foley et al. 2005; Harley 2011; Isbell et al. 2011; Cardinale et al. 2012), increases in natural disturbances such as insects and disease outbreaks (Aukema et al. 2006; Parkins and MacKendrick 2007;

Kurz et al. 2008; Boulanger et al. 2013), and increases in the frequency of wildfires (Stocks et al. 1998; Johnstone et al. 2010; Boulanger et al. 2013). Climate change may also have a significant impact on the economic gains from production functions and the provision services of forestry in boreal forest management (Pussinen et al. 2002; Briceno-Elizondo et al. 2008; Hanewinkel et al. 2013). The National Round Table on the Environment and Economy (NRTEE) estimated the economic loss to range between $\$ 2$ billion and $\$ 17$ billion per year by the year 2050 , due to the impacts of climate change on Canada's forest industry (Williamson et al. 2009). Therefore, climate change has implications for both economic gains and ecological losses in boreal forests, necessitating the requirement to study trade-offs across temporal and spatial scales.

Boreal forests in Canada comprise $\sim 90 \%$ of the total forested area of 417.6 million hectares, and close to one third of the global boreal forest area (Canadian Council of Forest Ministers 2005). Boreal forest industries contribute significantly to Canada's economy, as it is the world's leading exporter of forest products (Thompson and Pitt 2003; Wagner et al. 2006), including solid wood products (e.g., timber, lumber, fuelwood, and charcoal), pulp and paper, compositions and engineered wood, chemicals (e.g., acetic acid, acetone, and creosote), bioenergy (e.g., wood pellet), and non-timber products (Grebner et al. 2012). The magnitude of change of Canada's climate is anticipated to be substantially higher than that over the previous 100 years, which makes the ecological functions and ecosystem services of boreal forests very vulnerable (Williamson et al. 2009). However, our understanding of the economic and ecological trade-offs of Canada's boreal forests remains limited. Recent synthesis has called for further 
461 trade-off studies involving economic and ecological objectives, under the consequences of

462 climate change, to support forest management decisions and policy development for boreal

463 forests (Lempriere et al. 2013). Economic and ecological trade-off analysis will assist with

464 elucidating how mitigation might be integrated with adaptations to climate change under boreal

465 forest conditions (Adamowicz et al. 2003).

$466 \quad 6.2$ Trade-off analysis associated with disturbances

467

468

469

470

471

472 the economic gains and ecological services from boreal forests (Williamson et al. 2009; Venier

473 et al. 2014; Steffen et al. 2015). These disturbances are altering boreal forest ecosystems in

474 fundamental ways, with broad-ranging impacts on soil nutrients, carbon stocks, plant species

475 richness, evenness, composition, age-class distribution, and changes in productivity for timber

476 supply (Thomas et al. 2004; Venier et al. 2014; Clarke et al. 2015). However, the majority of the

477 reviewed trade-off studies in the literature did not consider disturbance impacts, which remains

478 an urgent issue to be addressed to maintain a balance between the economic gains and ecological

479 sustainability of boreal forests, which are susceptible to severe natural and anthropogenic

480 disturbances. 


\subsection{Inclusion of additional ecological functions and ecosystem services}

482

483

484

485

486

487

488

489

490

491

492

493

494

495

496

497

498

499

500

501

502

503
Previous trade-off studies conducted in boreal forests have focused only on the maximization of economic gains, and the maintenance of a certain level of biodiversity (mostly fauna) or habitat provision (Kangas and Pukkala 1996; Carlsson 1999; Seely et al. 2004; Zhou and Gong 2005; Andersson et al. 2006; Hurme et al. 2007; Juutinen and Monkkonen 2007;

Tikkanen et al. 2007; Briceno-Elizondo et al. 2008; McCarney et al. 2008; Hauer et al. 2010;

Ohman et al. 2011; Monkkonen et al. 2014), structural diversity (Kant 2002; Krcmar et al. 2005), carbon stocks or sequestration (Hoen and Solberg 1994; Krcmar et al. 2001; Pussinen et al. 2002; Seely et al. 2004; Backeus et al. 2005; Krcmar et al. 2005; Backeus et al. 2006; Garcia-Gonzalo et al. 2007; Briceno-Elizondo et al. 2008; McCarney et al. 2008; Pyorala et al. 2014; Trivino et al. 2015; Zubizarreta-Gerendiain et al. 2016), water regulation or supply (Raudsepp-Hearne et al. 2010), erosion protection and soil fertility (Raudsepp-Hearne et al. 2010), and cultural services (Zhou and Gong 2005; Ahtikoski et al. 2011) (Fig. 2). However, other critical ecological functions and ecosystem services have received less attention in economic and ecological tradeoff studies in response to boreal forest management activities. For example, forest-site productivity; linking tree growth with soil and plant nutrients across treatments, is central to the long-term economic and ecological sustainability of boreal forest ecosystems (Anyomi et al. 2014). Intensive forest management strategies that aim to maximize economic gains may not be optimal for the long-term sustainability of boreal forest site productivity. The core concern of site productivity is nutrient depletion, which is associated with biomass removal due to economic activities (MacLellan and Carleton 2003; LeBauer and Treseder 2008). Moreover, intensive forest management, which maximizes economic resources extraction, may also affect plant species diversity. Plant species diversity, including richness, evenness, and composition, reflects 
504 the variation, abundance, and ecological relationships among species at both genetic and

505 ecosystem levels (Purvis and Hector 2000). Evidence shows a positive relationship between

506 higher diversity with ecological functions and ecosystem services (Naeem and Wright 2003;

507 Balvanera et al. 2006; Zhang et al. 2012). Plant diversity also serves as a regulatory factor that 508 supports and controls fundamental ecological processes, and directly influences the delivery of 509 some ecosystem services (Hooper et al. 2005; Nelson et al. 2008; Isbell et al. 2011; Mace et al. 510 2012; Zhang et al. 2012). Economic-ecological trade-off research will benefit from the inclusion 511 of diverse ecological objectives, given the recent series of environmental reviews that have 512 facilitated the understanding of the wide array of biodiversity and ecological functions that 513 boreal forests provide (de Groot et al. 2010; Kurz et al. 2013; Lempriere et al. 2013; Price et al. 514 2013; Gauthier et al. 2014; Maynard et al. 2014; Venier et al. 2014; Webster et al. 2015) (Table 515 2).

$516 \quad 6.4$ Inclusion of multiple objectives in trade-off analysis with temporal and spatial 517 considerations

The scope of the reviewed literature conducted in boreal forests was generally limited to 519 two objectives. Only three studies considered three objectives (Seely et al. 2004; Krcmar et al.

520 2005; Briceno-Elizondo et al. 2008), one study focused on four objectives (Zhou and Gong 521 2005), and very few studies analyzed trade-offs involving multiple objectives simultaneously

522 (Raudsepp-Hearne et al. 2010; Monkkonen et al. 2014) (Table 1). Future trade-off analysis shall 523 simultaneously consider additional ecological objectives. Despite recent progress, the combination of spatially explicit and temporally dynamic 525 simulations with optimization approaches, for truly multi-objective purposes, has thus far 526 remained poorly developed. We propose the use of multi-objective optimization as a preferred 
527 method to provide a series of satisfactory optimal solutions for forest management, and to bridge

528 the gap for economic and ecological trade-off analysis with multiple ecological objectives across

529 both spatial and temporal scales, by integrating modeling techniques. Spatial concerns may be

530 added by using adjacency constraints or spatially explicit landscape simulation models in multi-

531 objective optimization, while the temporal scale may be included by conducting simulation

532 scenarios that span the entire planning horizon. Feedback from multiple options of forest

533 management decisions can be created as multiple scenarios using simulation models. The

534 parameters derived from these scenarios may then be employed, for decision-making and future

535 realistic predictions, using the multi-objective optimization technique.

536 Moreover, the extent and magnitude of climate change impacts on the ecological

537 functions and services of the boreal forests remain uncertain, as do the economic consequences

538 (Gauthier et al. 2015). However, an assessment of economic and ecological trade-offs for forest

539 management decision-making under the effects of climate change will necessitate the

540 consideration of the uncertainties that are associated with projected climate change scenarios

541 (Hanewinkel et al. 2013). These uncertain scenarios may have to rely on simulation models, and

542 trade-off analysis might be conducted by assessing sensitivities of economic opportunities and

543 ecological functions and services to the projected climate change using multi-objectives

544 techniques (Trivino et al. 2015).

\subsection{Inclusion of social aspects}

It is also important to develop forest management policies through exploring multi-

547 objectives modelling techniques that balance the needs of economic, ecological, as well as social 548 sustainability (Chapin et al. 2003). Especially in the context of boreal forests, where nearly $80 \%$ 549 of the Indigenous communities reside in the productive forest areas, and Indigenous Peoples rely 
550 on boreal forest resources for nutritional, social, cultural, spiritual, and other services and well-

551 beings (Stevenson and Webb 2003). It is also widely recognized that the success of crown forest

552 management mainly depends on the active participation of Indigenous communities (Saint-

553 Arnaud et al. 2009). Therefore, Indigenous Peoples and their social-economic aspects need to be 554 considered in the future economic and ecological trade-off studies in their traditional territories 555 in boreal forests.

556

557

558

559

560

561

562

563

564

565

566

567

568

569

570

\section{Conclusions}

Although intensive forest management practices maximize economic gains, the long-term impacts of these management practices on ecological functions and services have not been fully investigated. This review paper has examined the economic and ecological trade-off methods that are commonly employed in making forest management decisions, including monetary valuation, biophysical models, optimization programming, production possibility frontier, and multi-objective optimization. This review revealed that: (i) economic and ecological trade-offs are poorly understood for boreal forests; (ii) the analysis of economic and ecological trade-offs often includes limited ecological functions and ecosystem services; and (iii) multiple economic and ecological objectives are rarely considered in the trade-off studies of boreal forests.

Therefore, it remains uncertain how economic activities might best maintain and support multiple ecological functions and services in boreal forests under ongoing global climate change and increasing anthropogenic disturbances. We propose the use of multi-objective optimization techniques toward the realization of sustainable and optimal forest management solutions to support management decisions and policy development in the boreal forest and beyond. 


\section{Acknowledgements}

572 Financial support from the Natural Sciences and Engineering Research Council of Canada

573 (DG281886-09 and STPGP428641) is gratefully acknowledged. 


\section{References}

575 Adamowicz, W.L., Armstrong, G.W., and Messmer, M.J. 2003. The economics of boreal forest

576 management in (eds.) Burton, P. J.; Messier, C.; Smith, D. W.; Adamowicz, W. L., Towards

577 sustainable management of the boreal forest. pp. 181-211. NRC Research Press.

578 Adams, W.M. 2014. Conservation. The value of valuing nature. Science 346(6209): 549-551.

579 doi: 10.1126/science.1255997.

580 Admiraal, J.F., Wossink, A., de Groot, W.T., and de Snoo, G.R. 2013. More than total economic

581 value: How to combine economic valuation of biodiversity with ecological resilience. Ecological

582 Economics 89: 115-122. doi: 10.1016/j.ecolecon.2013.02.009.

583 Ahtikoski, A., Tuulentie, S., Hallikainen, V., Nivala, V., Vatanen, E., Tyrvainen, L., and

584 Salminen, H. 2011. Potential Trade-Offs Between Nature-Based Tourism and Forestry, a Case

585 Study in Northern Finland. Forests 2(4): 894-912. doi: 10.3390/f2040894.

586 Allen, C.D., Macalady, A.K., Chenchouni, H., Bachelet, D., McDowell, N., Vennetier, M.,

587 Kitzberger, T., Rigling, A., Breshears, D.D., Hogg, E.H., Gonzalez, P., Fensham, R., Zhang, Z.,

588 Castro, J., Demidova, N., Lim, J.H., Allard, G., Running, S.W., Semerci, A., and Cobb, N. 2010.

589 A global overview of drought and heat-induced tree mortality reveals emerging climate change

590 risks for forests. Forest Ecology and Management 259(4): 660-684. doi:

$591 \quad$ 10.1016/j.foreco.2009.09.001.

592 Andersson, M., Sallnas, O., and Carlsson, M. 2006. A landscape perspective on differentiated

593 management for production of timber and nature conservation values. Forest Policy Econ. 9(2):

594 153-161. doi: 10.1016/j.forpol.2005.04.002. 
595 Anyomi, K.A., Raulier, F., Bergeron, Y., Mailly, D., and Girardin, M.P. 2014. Spatial and 596 temporal heterogeneity of forest site productivity drivers: a case study within the eastern boreal 597 forests of Canada. Landscape Ecology 29(5): 905-918. doi: 10.1007/s10980-014-0026-y. 598 Arthaud, G.J., and Rose, D.W. 1996. A methodology for estimating production possibility 599 frontiers for wildlife habitat and timber value at the landscape level. Can J Forest Res 26(12): 600 2191-2200. doi: 10.1139/x26-248.

601 Attiwill, P.M. 1994. The Disturbance of Forest Ecosystems - the Ecological Basis for 602 Conservative Management. Forest Ecology and Management 63(2-3): 247-300. doi: $603 \quad 10.1016 / 0378-1127(94) 90114-7$.

604 Aukema, B.H., Carroll, A.L., Zhu, J., Raffa, K.F., Sickley, T.A., and Taylor, S.W. 2006.

605 Landscape level analysis of mountain pine beetle in British Columbia, Canada: spatiotemporal 606 development and spatial synchrony within the present outbreak. Ecography 29(3): 427-441. doi: $607 \quad 10.1111 /$ j.2006.0906-7590.04445.x.

608 Backeus, S., Wikstrom, P., and Lamas, T. 2005. A model for regional analysis of carbon 609 sequestration and timber production. Forest Ecology and Management 216(1-3): 28-40. doi: $610 \quad$ 10.1016/j.foreco.2005.05.059.

611 Backeus, S., Wikstrom, P., and Lamas, T. 2006. Modeling carbon sequestration and timber 612 production in a regional case study. Silva Fennica 40(4): 615-629. doi: 10.14214/sf.318.

613 Balmford, A., Bruner, A., Cooper, P., Costanza, R., Farber, S., Green, R.E., Jenkins, M., 614 Jefferiss, P., Jessamy, V., Madden, J., Munro, K., Myers, N., Naeem, S., Paavola, J., Rayment, 615 M., Rosendo, S., Roughgarden, J., Trumper, K., and Turner, R.K. 2002. Economic reasons for 616 conserving wild nature. Science 297(5583): 950-953. doi: 10.1126/science. 1073947. 
617 Balvanera, P., Pfisterer, A.B., Buchmann, N., He, J.S., Nakashizuka, T., Raffaelli, D., and

618 Schmid, B. 2006. Quantifying the evidence for biodiversity effects on ecosystem functioning and 619 services. Ecol Lett 9(10): 1146-1156. doi: 10.1111/j.1461-0248.2006.00963.x.

620 Baskent, E.Z., Keles, S., Kadiogullari, A.I., and Bingol, O. 2011. Quantifying the Effects of 621 Forest Management Strategies on the Production of Forest Values: Timber, Carbon, Oxygen, 622 Water, and Soil. Environmental Modeling \& Assessment 16(2): 145-152. doi: 10.1007/s10666$623 \quad 010-9238-y$.

624 Baskent, E.Z., Keles, S., and Yolasigmaz, H.A. 2008. Comparing multipurpose forest 625 management with timber management, incorporating timber, carbon and oxygen values: A case 626 study. Scandinavian Journal of Forest Research 23(2): 105-120. doi:

$627 \quad 10.1080 / 02827580701803536$.

628 Bateman, I.J., Harwood, A.R., Mace, G.M., Watson, R.T., Abson, D.J., Andrews, B., Binner, A., 629 Crowe, A., Day, B.H., Dugdale, S., Fezzi, C., Foden, J., Hadley, D., Haines-Young, R., Hulme, 630 M., Kontoleon, A., Lovett, A.A., Munday, P., Pascual, U., Paterson, J., Perino, G., Sen, A., 631 Siriwardena, G., van Soest, D., and Termansen, M. 2013. Ecosystem services: response. Science 632 342(6157): 421-422. doi: 10.1126/science.342.6157.421-b.

633 Bennett, E.M., Peterson, G.D., and Gordon, L.J. 2009. Understanding relationships among 634 multiple ecosystem services. Ecol Lett 12(12): 1394-1404. doi: 10.1111/j.1461$635 \quad 0248.2009 .01387 . x$

636 Bettinger, P., Boston, K., and Sessions, J. 1999. Combinatorial optimization of elk habitat 637 effectiveness and timber harvest volume. Environmental Modeling and Assessment 4(2/3): 143638 153. doi: 10.1023/a:1019051931272. 
639 Bettinger, P., Johnson, D.L., and Johnson, K.N. 2003. Spatial forest plan development with 640 ecological and economic goals. Ecological Modelling 169(2-3): 215-236. doi: 10.1016/S0304$6413800(03) 00271-0$.

642 Bettinger, P., Sessions, J., and Boston, K. 1997. Using Tabu search to schedule timber harvests 643 subject to spatial wildlife goals for big game. Ecological Modelling 94(2-3): 111-123. doi:

$644 \quad 10.1016 / \mathrm{S} 0304-3800(96) 00007-5$.

645 Bettinger, P., Sessions, J., and Johnson, K.N. 1998. Ensuring the compatibility of aquatic habitat 646 and commodity production goals in eastern Oregon with a Tabu search procedure. Forest Science 647 44(1): 96-112.

648 Boland, G.J., Melzer, M.S., Hopkin, A., Higgins, V., and Nassuth, A. 2004. Climate change and 649 plant diseases in Ontario. Can J Plant Pathol 26(3): 335-350. doi: 10.1080/07060660409507151. 650 Boscolo, M., and Buongiorno, J. 1997. Managing a tropical rainforest for timber, carbon storage 651 and tree diversity. The Commonwealth Forestry Review 26(3): 246-254.

652 Boscolo, M., and Buongiorno, J. 2000. Carbon Storage, Income, and Habitat Diversity in 653 Managed Tropical Forests. United States Department of Agriculture Forest Service General 654 Technical Report NC: 144-149.

655 Boscolo, M., Buongiorno, J., and Panayotou, T. 1997. Simulating options for carbon 656 sequestration through improved management of a lowland tropical rainforest. Environment and 657 Development Economics 2(3): 241-263. doi: 10.1017/s1355770x97000028.

658 Boscolo, M., and Vincent, J.R. 2003. Nonconvexities in the production of timber, biodiversity, 659 and carbon sequestration. Journal of Environmental Economics and Management 46(2): 251660 268. doi: 10.1016/S0095-0696(02)00034-7. 
661 Bottalico, F., Pesola, L., Vizzarri, M., Antonello, L., Barbati, A., Chirici, G., Corona, P.,

662 Cullotta, S., Garfi, V., Giannico, V., Lafortezza, R., Lombardi, F., Marchetti, M., Nocentini, S.,

663 Riccioli, F., Travaglini, D., and Sallustio, L. 2016. Modeling the influence of alternative forest

664 management scenarios on wood production and carbon storage: A case study in the

665 Mediterranean region. Environ Res 144(Pt B): 72-87. doi: 10.1016/j.envres.2015.10.025.

666 Bottazzi, P., Crespo, D., Soria, H., Dao, H., Serrudo, M., Benavides, J.P., Schwarzer, S., and

667 Rist, S. 2014. Carbon Sequestration in Community Forests: Trade-offs, Multiple Outcomes and

668 Institutional Diversity in the Bolivian Amazon. Development and Change 45(1): 105-131. doi:

$669 \quad 10.1111 /$ dech.12076.

670 Boulanger, Y., Gauthier, S., Gray, D.R., Le Goff, H., Lefort, P., and Morissette, J. 2013. Fire

671 regime zonation under current and future climate over eastern Canada. Ecological applications :

672 a publication of the Ecological Society of America 23(4): 904-923.

673 Bouman, B.A.M., Schipper, R.A., Nieuwenhuyse, A., Hengsdijk, H., and Jansen, H.G.P. 1998.

674 Quantifying economic and biophysical sustainability trade-offs in land use exploration at the

675 regional level: a case study for the Northern Atlantic Zone of Costa Rica. Ecological Modelling

676 114(1): 95-109. doi: 10.1016/S0304-3800(98)00121-5.

677 Brandt, J.P. 2009. The extent of the North American boreal zone. Environ Rev 17(NA): 101-161.

678 doi: 10.1139/A09-004.

679 Brandt, J.P., Flannigan, M.D., Maynard, D.G., Thompson, I.D., and Volney, W.J.A. 2013. An

680 introduction to Canada's boreal zone: ecosystem processes, health, sustainability, and

681 environmental issues. Environ Rev 21(4): 207-226. doi: 10.1139/er-2013-0040.

682 Briceno-Elizondo, E., Jager, D., Lexer, M.J., Garcia-Gonzalo, J., Peltola, H., and Kellomaki, S.

683 2008. Multi-criteria evaluation of multi-purpose stand treatment programmes for Finnish boreal 
684 forests under changing climate. Ecological Indicators 8(1): 26-45. doi:

$685 \quad 10.1016 /$ j.ecolind.2006.12.001.

686 Buongiorno, J., Dahir, S., Lu, H.C., and Lin, C.R. 1994. Tree Size Diversity and Economic

687 Returns in Uneven-Aged Forest Stands. Forest Science 40(1): 83-103.

688 Buongiorno, J., Peyron, J.L., Houllier, F., and Bruciamacchie, M. 1995. Growth and

689 Management of Mixed-Species, Uneven-Aged Forests in the French Jura - Implications for

690 Economic Returns and Tree Diversity. Forest Science 41(3): 397-429.

691 Burton, P.J., Messier, C., Adamowicz, W.L., and Kuuluvainen, T. 2006. Sustainable

692 management of Canada's boreal forests: Progress and prospects. Ecoscience 13(2): 234-248. doi:

$693 \quad 10.2980 /$ i1 195-6860-13-2-234.1.

694 Cademus, R., Escobedo, F.J., McLaughlin, D., and Abd-Elrahman, A. 2014. Analyzing Trade-

695 Offs, Synergies, and Drivers among Timber Production, Carbon Sequestration, and Water Yield

696 in Pinus elliotii Forests in Southeastern USA. Forests 5(6): 1409-1431. doi: 10.3390/f5061409.

697 Calkin, D.E., Montgomery, C.A., Schumaker, N.H., Polasky, S., Arthur, J.L., and Nalle, D.J.

698 2002. Developing a production possibility set of wildlife species persistence and timber harvest

699 value. Can J Forest Res 32(8): 1329-1342. doi: 10.1139/X02-056.

700 Canadian Council of Forest Ministers. 2005. Criteria and indicators of sustainable forest

701 management in Canada: National status 2005. Natural Resouces Canada, Canadian Forest

702 Service, Ottawa, Ontario, Canada.

703 Cardinale, B.J., Duffy, J.E., Gonzalez, A., Hooper, D.U., Perrings, C., Venail, P., Narwani, A.,

704 Mace, G.M., Tilman, D., Wardle, D.A., Kinzig, A.P., Daily, G.C., Loreau, M., Grace, J.B.,

705 Larigauderie, A., Srivastava, D.S., and Naeem, S. 2012. Biodiversity loss and its impact on

706 humanity. Nature 486(7401): 59-67. doi: 10.1038/nature11148. 
707 Carlsson, M. 1999. A method for integrated planning of timber production and biodiversity: a

708 case study. Can J Forest Res 29(8): 1183-1191. doi: 10.1139/cjfr-29-8-1183.

709 Carreno, L., Frank, F.C., and Viglizzo, E.F. 2012. Tradeoffs between economic and ecosystem

710 services in Argentina during 50 years of land-use change. Agriculture Ecosystems \&

711 Environment 154: 68-77. doi: 10.1016/j.agee.2011.05.019.

712 Chapin, F.S., 3rd, Lovecraft, A.L., Zavaleta, E.S., Nelson, J., Robards, M.D., Kofinas, G.P.,

713 Trainor, S.F., Peterson, G.D., Huntington, H.P., and Naylor, R.L. 2006. Policy strategies to

714 address sustainability of Alaskan boreal forests in response to a directionally changing climate.

715 Proc Natl Acad Sci U S A 103(45): 16637-16643. doi: 10.1073/pnas.0606955103.

716 Chapin, F.S., 3rd, Zavaleta, E.S., Eviner, V.T., Naylor, R.L., Vitousek, P.M., Reynolds, H.L.,

717 Hooper, D.U., Lavorel, S., Sala, O.E., Hobbie, S.E., Mack, M.C., and Diaz, S. 2000.

718 Consequences of changing biodiversity. Nature 405(6783): 234-242. doi: 10.1038/35012241.

719 Chapin, F.S., Rupp, T.S., Starfield, A.M., DeWilde, L.O., Zavaleta, E.S., Fresco, N., Henkelman, 720 J., and McGuire, A.D. 2003. Planning for resilience: modeling change in human-fire interactions

721 in the Alaskan boreal forest. Frontiers in Ecology and the Environment 1(5): 255-261. doi:

722 10.1890/1540-9295(2003)001[0255:Pfrmci]2.0.Co;2.

723 Chen, H.Y., and Luo, Y. 2015. Net aboveground biomass declines of four major forest types

724 with forest ageing and climate change in western Canada's boreal forests. Glob Chang Biol

725 21(10): 3675-3684. doi: 10.1111/gcb.12994.

726 Chopra, K., and Kumar, P. 2004. Forest biodiversity and timber extraction: an analysis of the

727 interaction of market and non-market mechanisms. Ecological Economics 49(2): 135-148. doi:

$728 \quad 10.1016 / j . e c o l e c o n .2004 .03 .024$. 
729 Clarke, N., Gundersen, P., Jonsson-Belyazid, U., Kjonaas, O.J., Persson, T., Sigurdsson, B.D., 730 Stupak, I., and Vesterdal, L. 2015. Influence of different tree-harvesting intensities on forest soil 731 carbon stocks in boreal and northern temperate forest ecosystems. Forest Ecology and 732 Management 351: 9-19. doi: 10.1016/j.foreco.2015.04.034.

733 Clough, Y., Barkmann, J., Juhrbandt, J., Kessler, M., Wanger, T.C., Anshary, A., Buchori, D., 734 Cicuzza, D., Darras, K., Putra, D.D., Erasmi, S., Pitopang, R., Schmidt, C., Schulze, C.H., 735 Seidel, D., Steffan-Dewenter, I., Stenchly, K., Vidal, S., Weist, M., Wielgoss, A.C., and 736 Tscharntke, T. 2011. Combining high biodiversity with high yields in tropical agroforests. Proc 737 Natl Acad Sci U S A 108(20): 8311-8316. doi: 10.1073/pnas.1016799108.

738 Cordingley, J.E., Newton, A.C., Rose, R.J., Clarke, R.T., Bullock, J.M., and Mori, A. 2016. Can 739 landscape-scale approaches to conservation management resolve biodiversity-ecosystem service 740 trade-offs? Journal of Applied Ecology 53(1): 96-105. doi: 10.1111/1365-2664.12545.

Costanza, R., dArge, R., deGroot, R., Farber, S., Grasso, M., Hannon, B., Limburg, K., Naeem, S., ONeill, R.V., Paruelo, J., Raskin, R.G., Sutton, P., and vandenBelt, M. 1997. The value of the world's ecosystem services and natural capital. Nature 387(6630): 253-260. doi:

745 Costanza, R., de Groot, R., Sutton, P., van der Ploeg, S., Anderson, S.J., Kubiszewski, I., Farber, 746 S., and Turner, R.K. 2014. Changes in the global value of ecosystem services. Global

747 Environmental Change-Human and Policy Dimensions 26: 152-158. doi:

$748 \quad$ 10.1016/j.gloenvcha.2014.04.002.

749 Dale, V.H., Joyce, L.A., McNulty, S., Neilson, R.P., Ayres, M.P., Flannigan, M.D., Hanson, P.J., 750 Irland, L.C., Lugo, A.E., Peterson, C.J., Simberloff, D., Swanson, F.J., Stocks, B.J., and Wotton, 
751 B.M. 2001. Climate change and forest disturbances. Bioscience 51(9): 723-734. doi:

752 10.1641/0006-3568(2001)051[0723:Ccafd]2.0.Co;2.

753 de Groot, R., Brander, L., van der Ploeg, S., Costanza, R., Bernard, F., Braat, L., Christie, M.,

754 Crossman, N., Ghermandi, A., Hein, L., Hussain, S., Kumar, P., McVittie, A., Portela, R., 755 Rodriguez, L.C., ten Brink, P., and van Beukering, P. 2012. Global estimates of the value of 756 ecosystems and their services in monetary units. Ecosystem Services 1(1): 50-61. doi:

757 10.1016/j.ecoser.2012.07.005.

758 de Groot, R.S., Alkemade, R., Braat, L., Hein, L., and Willemen, L. 2010. Challenges in 759 integrating the concept of ecosystem services and values in landscape planning, management and 760 decision making. Ecological Complexity 7(3): 260-272. doi: 10.1016/j.ecocom.2009.10.006.

761 de Groot, R.S., Wilson, M.A., and Boumans, R.M.J. 2002. A typology for the classification, 762 description and valuation of ecosystem functions, goods and services. Ecological Economics 763 41(3): 393-408. doi: 10.1016/s0921-8009(02)00089-7.

764 DeFries, R.S., Foley, J.A., and Asner, G.P. 2004. Land-use choices: balancing human needs and 765 ecosystem function. Frontiers in Ecology and the Environment 2(5): 249-257. doi:

766 10.1890/1540-9295(2004)002[0249:Lcbhna]2.0.Co;2.

767 Díaz-Balteiro, L., and Romero, C. 2003. Forest management optimisation models when carbon 768 captured is considered: a goal programming approach. Forest Ecology and Management 174(1769 3): 447-457. doi: 10.1016/s0378-1127(02)00075-0.

770 Diffenbaugh, N.S., and Field, C.B. 2013. Changes in ecologically critical terrestrial climate 771 conditions. Science 341(6145): 486-492. doi: 10.1126/science.1237123. 
772 Doherty, P.F., Marschall, E.A., and Grubb, T.C. 1999. Balancing conservation and economic

773 gain: a dynamic programming approach. Ecological Economics 29(3): 349-358. doi:

$774 \quad 10.1016 / \mathrm{S} 0921-8009(98) 00057-3$.

775 Duncker, P.S., Raulund-Rasmussen, K., Gundersen, P., Katzensteiner, K., De Jong, J., Ravn, 776 H.P., Smith, M., Eckmullner, O., and Spiecker, H. 2012. How Forest Management affects

777 Ecosystem Services, including Timber Production and Economic Return: Synergies and Trade778 Offs. Ecology and Society 17(4). doi: Artn 50

$779 \quad 10.5751 /$ Es-05066-170450.

780 Faith, D.P., Margules, C.R., and Walker, P. 2001. A biodiversity conservation plan for Papua 781 New Guinea based on biodiversity trade-offs analysis. Pacific Conservation Biology 6(4): 304782 324. doi: 10.1071/PC010304.

783 Faith, D.P., and Walker, P.A. 2002. The role of trade-offs in biodiversity conservation planning:

784 linking local management, regional planning and global conservation efforts. J Biosci 27(4 Suppl 785 2): 393-407. doi: 10.1007/BF02704968.

786 Faith, D.P., Walker, P.A., Ive, J.R., and Belbin, L. 1996. Integrating conservation and forestry 787 production: Exploring trade-offs between biodiversity and production in regional land-use 788 assessment. Forest Ecology and Management 85(1-3): 251-260. doi: 10.1016/S0378$789 \quad 1127(96) 03762-0$.

790 Farber, S., Costanza, R., Childers, D.L., Erickson, J., Gross, K., Grove, M., Hopkinson, C.S., 791 Kahn, J., Pincetl, S., Troy, A., Warren, P., and Wilson, M. 2006. Linking ecology and economics 792 for ecosystem management. Bioscience 56(2): 121-133. doi: 10.1641/0006$793 \quad 3568(2006) 056[0121:$ Leaefe $] 2.0 . \mathrm{Co} ; 2$. 
794 Farley, J. 2008. The role of prices in conserving critical natural capital. Conservation biology:

795 the journal of the Society for Conservation Biology 22(6): 1399-1408. doi: 10.1111/j.1523-

$796 \quad 1739.2008 .01090 . x$.

797 Femia, A., Hinterberger, F., and Luks, F. 2001. Ecological economic policy for sustainable 798 development: potentials and domains of intervention for delinking approaches. Population and 799 Environment 23(2): 157-174.

800 Ferraro, P.J., and Kiss, A. 2002. Ecology. Direct payments to conserve biodiversity. Science 801 298(5599): 1718-1719. doi: 10.1126/science.1078104.

802 Foley, J.A., Defries, R., Asner, G.P., Barford, C., Bonan, G., Carpenter, S.R., Chapin, F.S., Coe, 803 M.T., Daily, G.C., Gibbs, H.K., Helkowski, J.H., Holloway, T., Howard, E.A., Kucharik, C.J., 804 Monfreda, C., Patz, J.A., Prentice, I.C., Ramankutty, N., and Snyder, P.K. 2005. Global 805 consequences of land use. Science 309(5734): 570-574. doi: 10.1126/science.1111772.

806 Furstenau, C., Badeck, F.W., Lasch, P., Lexer, M.J., Lindner, M., Mohr, P., and Suckow, F. 807 2007. Multiple-use forest management in consideration of climate change and the interests of 808 stakeholder groups. European Journal of Forest Research 126(2): 225-239. doi: 10.1007/s10342809 006-0114-x.

810 Garcia-Gonzalo, J., Bushenkov, V., McDill, M.E., and Borges, J.G. 2015. A Decision Support 811 System for Assessing Trade-Offs between Ecosystem Management Goals: An Application in 812 Portugal. Forests 6(1): 65-87. doi: 10.3390/f6010065.

813 Garcia-Gonzalo, J., Peltola, H., Gerendiain, A.Z., and Kellomaki, S. 2007. Impacts of forest 814 landscape structure and management on timber production and carbon stocks in the boreal forest 815 ecosystem under changing climate. Forest Ecology and Management 241(1-3): 243-257. doi: $81610.1016 /$ j.foreco.2007.01.008. 
817 Gatto, M., and De Leo, G.A. 2000. Pricing biodiversity and ecosystem services: The never-

818 ending story. Bioscience 50(4): 347-355. doi: 10.1641/0006-

819 3568(2000)050[0347:Pbaest $] 2.3 . C 0 ; 2$.

820 Gauthier, S., Bernier, P., Burton, P.J., Edwards, J., Isaac, K., Isabel, N., Jayen, K., Le Goff, H., 821 and Nelson, E.A. 2014. Climate change vulnerability and adaptation in the managed Canadian 822 boreal forest. Environ Rev 22(3): 256-285. doi: 10.1139/er-2013-0064.

823 Gauthier, S., Bernier, P., Kuuluvainen, T., Shvidenko, A.Z., and Schepaschenko, D.G. 2015.

824 Boreal forest health and global change. Science 349(6250): 819-822. doi:

$82510.1126 /$ science.aaa9092.

826 Gissi, E., Gaglio, M., and Reho, M. 2016. Sustainable energy potential from biomass through

827 ecosystem services trade-off analysis: The case of the Province of Rovigo (Northern Italy).

828 Ecosystem Services 18: 1-19. doi: 10.1016/j.ecoser.2016.01.004.

829 Godoy, R., Wilkie, D., Overman, H., Cubas, A., Cubas, G., Demmer, J., McSweeney, K., and 830 Brokaw, N. 2000. Valuation of consumption and sale of forest goods from a Central American 831 rain forest. Nature 406(6791): 62-63. doi: 10.1038/35017647.

832 Goldstein, J.H., Caldarone, G., Duarte, T.K., Ennaanay, D., Hannahs, N., Mendoza, G., Polasky, 833 S., Wolny, S., and Daily, G.C. 2012. Integrating ecosystem-service tradeoffs into land-use 834 decisions. Proc Natl Acad Sci U S A 109(19): 7565-7570. doi: 10.1073/pnas.1201040109.

835 Grasso, M. 1998. Ecological-economic model for optimal mangrove trade off between forestry 836 and fishery production: comparing a dynamic optimization and a simulation model. Ecological

837 Modelling 112(2-3): 131-150. doi: 10.1016/S0304-3800(98)00076-3.

838 Grebner, D.L., Bettinger, P., and Siry, J.P. 2012. Introduction to forestry and natural resources. 839 Academic Press, Waltham, USA. pp. 98-114. 
840 Gret-Regamey, A., Brunner, S.H., Altwegg, J., Christen, M., and Bebi, P. 2013. Integrating

841 Expert Knowledge into Mapping Ecosystem Services Trade-offs for Sustainable Forest

842 Management. Ecology and Society 18(3): 34. doi: Unsp 34

$843 \quad 10.5751 /$ Es-05800-180334.

844 Hanewinkel, M., Cullmann, D.A., Schelhaas, M.J., Nabuurs, G.J., and Zimmermann, N.E. 2013.

845 Climate change may cause severe loss in the economic value of European forest land. Nature

846 Climate Change 3(3): 203-207. doi: 10.1038/Nclimate1687.

847 Hansen, A.J., Garman, S.L., Weigand, J.F., Urban, D.L., Mccomb, W.C., and Raphael, M.G.

848 1995. Alternative Silvicultural Regimes in the Pacific-Northwest - Simulations of Ecological and

849 Economic-Effects. Ecological Applications 5(3): 535-554. doi: 10.2307/1941965.

850 Harley, C.D.G. 2011. Climate Change, Keystone Predation, and Biodiversity Loss. Science

851 334(6059): 1124-1127. doi: 10.1126/science.1210199.

852 Hauer, G., Cumming, S., Schmiegelow, F., Adamowicz, W., Weber, M., and Jagodzinski, R.

853 2010. Tradeoffs between forestry resource and conservation values under alternate policy

854 regimes: A spatial analysis of the western Canadian boreal plains. Ecological Modelling 221(21):

855 2590-2603. doi: 10.1016/j.ecolmodel.2010.07.013.

856 Heal, G. 2000. Valuing ecosystem services. Ecosystems 3(1): 24-30. doi:

$857 \quad 10.1007 / \mathrm{s} 100210000006$.

858 Hiroshima, T. 2004. A linear programming approach to evaluating criteria and indicators for 859 sustainable forest management in Japan. In International Perspectives on Streamlining Local860 Level Information for Sustainable Forest Management. Edited by J.L. Innes and G.M. Hickey 861 and B. Wilson. pp. 83-93. 
862 Hoen, H.F., and Solberg, B. 1994. Potential and Economic-Efficiency of Carbon Sequestration in 863 Forest Biomass through Silvicultural Management. Forest Science 40(3): 429-451.

864 Holland, D.N., Lilieholm, R.J., Roberts, D.W., and Gilless, J.K. 1994. Economic Trade-Offs of 865 Managing Forests for Timber Production and Vegetative Diversity. Can J Forest Res 24(6): 866 1260-1265. doi: 10.1139/x94-165.

867 Holling, C.S., and Meffe, G.K. 1996. Command and control and the pathology of natural 868 resource management. Conservation Biology 10(2): 328-337. doi: 10.1046/j.1523-

$869 \quad 1739.1996 .10020328 . x$.

870 Hooper, D.U., Chapin, F.S., Ewel, J.J., Hector, A., Inchausti, P., Lavorel, S., Lawton, J.H., 871 Lodge, D.M., Loreau, M., Naeem, S., Schmid, B., Setala, H., Symstad, A.J., Vandermeer, J., and 872 Wardle, D.A. 2005. Effects of biodiversity on ecosystem functioning: A consensus of current 873 knowledge. Ecological Monographs 75(1): 3-35. doi: 10.1890/04-0922.

874 Howe, C., Suich, H., Vira, B., and Mace, G.M. 2014. Creating win-wins from trade-offs?

875 Ecosystem services for human well-being: A meta-analysis of ecosystem service trade-offs and 876 synergies in the real world. Global Environmental Change 28: 263-275. doi:

877 10.1016/j.gloenvcha.2014.07.005.

878 Hurme, E., Kurttila, M., Monkkonen, M., Heinonen, T., and Pukkala, T. 2007. Maintenance of 879 flying squirrel habitat and timber harvest: a site-specific spatial model in forest planning 880 calculations. Landscape Ecology 22(2): 243-256. doi: 10.1007/s10980-006-9019-9.

881 Ingram, C.D., and Buongiorno, J. 1996. Income and diversity tradeoffs from management of 882 mixed lowland dipterocarps in Malaysia. Journal of Tropical Forest Science 9(2): 242-270.

883 Isbell, F., Calcagno, V., Hector, A., Connolly, J., Harpole, W.S., Reich, P.B., Scherer-Lorenzen, 884 M., Schmid, B., Tilman, D., van Ruijven, J., Weigelt, A., Wilsey, B.J., Zavaleta, E.S., and 
885 Loreau, M. 2011. High plant diversity is needed to maintain ecosystem services. Nature 886 477(7363): 199-202. doi: 10.1038/nature10282.

887 Johnstone, J.F., Hollingsworth, T.N., Chapin, F.S., and Mack, M.C. 2010. Changes in fire regime 888 break the legacy lock on successional trajectories in Alaskan boreal forest. Global Change 889 Biology 16(4): 1281-1295. doi: 10.1111/j.1365-2486.2009.02051.x.

890 Juutinen, A., and Monkkonen, M. 2007. Alternative targets and economic efficiency of selecting 891 protected areas for biodiversity conservation in boreal forest. Environmental \& Resource 892 Economics 37(4): 713-732. doi: 10.1007/s10640-006-9064-5.

893 Kangas, J., and Kangas, A. 2005. Multiple criteria decision support in forest management - the 894 approach, methods applied, and experiences gained. Forest Ecology and Management 207(1-2): 895 133-143. doi: 10.1016/j.foreco.2004.10.023.

896 Kangas, J., and Pukkala, T. 1996. Operationalization of biological diversity as a decision 897 objective in tactical forest planning. Can J Forest Res 26(1): 103-111. doi: 10.1139/x26-011. 898 Kant, S. 2002. The marginal cost of structural diversity of mixed uneven-aged hard maple 899 forests. Can J Forest Res 32(4): 616-628. doi: 10.1139/X02-001.

900 Kirilenko, A.P., and Sedjo, R.A. 2007. Climate change impacts on forestry. Proc Natl Acad Sci 901 U S A 104(50): 19697-19702. doi: 10.1073/pnas.0701424104.

902 Krcmar, E., Stennes, B., van Kooten, G.C., and Vertinsky, I. 2001. Carbon sequestration and 903 land management under uncertainty. European Journal of Operational Research 135(3): 616-629. 904 doi: 10.1016/S0377-2217(00)00326-X.

905 Krcmar, E., van Kooten, G.C., and Vertinsky, I. 2005. Managing forest and marginal agricultural 906 land for multiple tradeoffs: compromising on economic, carbon and structural diversity 907 objectives. Ecological Modelling 185(2-4): 451-468. doi: 10.1016/j.ecolmodel.2004.12.014. 
908 Kurz, W.A., Dymond, C.C., Stinson, G., Rampley, G.J., Neilson, E.T., Carroll, A.L., Ebata, T., 909 and Safranyik, L. 2008. Mountain pine beetle and forest carbon feedback to climate change.

910 Nature 452(7190): 987-990. doi: 10.1038/nature06777.

911 Kurz, W.A., Shaw, C.H., Boisvenue, C., Stinson, G., Metsaranta, J., Leckie, D., Dyk, A., Smyth, 912 C., and Neilson, E.T. 2013. Carbon in Canada's boreal forest - A synthesis. Environ Rev 21(4): 913 260-292. doi: 10.1139/er-2013-0041.

914 Landres, P.B., Morgan, P., and Swanson, F.J. 1999. Overview of the use of natural variability 915 concepts in managing ecological systems. Ecological Applications 9(4): 1179-1188. doi:

$916 \quad 10.2307 / 2641389$.

917 LeBauer, D.S., and Treseder, K.K. 2008. Nitrogen limitation of net primary productivity in 918 terrestrial ecosystems is globally distributed. Ecology 89(2): 371-379. doi: 10.1890/06-2057.1. 919 Lee, P. 2004. Boreal Canada: State of the Ecosystem, State of Industry, Emerging Issues and 920 Projections. Report to the National Round Table on the Environment and the Economy. Global 921 Forest Watch Canada. Edmonton.

922 Lempriere, T.C., Kurz, W.A., Hogg, E.H., Schmoll, C., Rampley, G.J., Yemshanov, D., 923 McKenney, D.W., Gilsenan, R., Beatch, A., Blain, D., Bhatti, J.S., and Krcmar, E. 2013. 924 Canadian boreal forests and climate change mitigation. Environ Rev 21(4): 293-321. doi: 925 10.1139/er-2013-0039.

926 Lichtenstein, M.E., and Montgomery, C.A. 2003. Biodiversity and timber in the Coast Range of 927 Oregon: Inside the production possibility frontier. Land Economics 79(1): 56-73. doi:

$928 \quad 10.2307 / 3147105$. 
929 Lin, C.R., and Buongiorno, J. 1998. Tree diversity, landscape diversity, and economics of maple930 birch forests: Implications of Markovian models. Management Science 44(10): 1351-1366. doi: $931 \quad 10.1287 / \mathrm{mnsc} .44 .10 .1351$.

932 Luo, Y., and Chen, H.Y. 2015. Climate change-associated tree mortality increases without 933 decreasing water availability. Ecol Lett 18(11): 1207-1215. doi: 10.1111/ele.12500.

934 Lutz, D.A., Burakowski, E.A., Murphy, M.B., Borsuk, M.E., Niemiec, R.M., and Howarth, R.B. 935 2015. Tradeoffs between three forest ecosystem services across the state of New Hampshire, 936 USA: timber, carbon, and albedo. Ecological Applications: 150512173442001. doi: 10.1890/14$937 \quad 2207.1$.

938 Ma, Z., Peng, C., Zhu, Q., Chen, H., Yu, G., Li, W., Zhou, X., Wang, W., and Zhang, W. 2012. 939 Regional drought-induced reduction in the biomass carbon sink of Canada's boreal forests. Proc 940 Natl Acad Sci U S A 109(7): 2423-2427. doi: 10.1073/pnas.1111576109.

941 Mace, G.M., Norris, K., and Fitter, A.H. 2012. Biodiversity and ecosystem services: a 942 multilayered relationship. Trends Ecol Evol 27(1): 19-26. doi: 10.1016/j.tree.2011.08.006. 943 MacLellan, J.I., and Carleton, T.J. 2003. Rational forest productivity decline. Environ Monit 944 Assess 86(1-2): 183-201. doi: 10.1023/a:1024066904728.

945 Maroschek, M., Rammer, W., and Lexer, M.J. 2015. Using a novel assessment framework to 946 evaluate protective functions and timber production in Austrian mountain forests under climate 947 change. Regional Environmental Change 15(8): 1543-1555. doi: 10.1007/s10113-014-0691-z.

948 Martin-Lopez, B., Iniesta-Arandia, I., Garcia-Llorente, M., Palomo, I., Casado-Arzuaga, I., Amo, 949 D.G., Gomez-Baggethun, E., Oteros-Rozas, E., Palacios-Agundez, I., Willaarts, B., Gonzalez, 950 J.A., Santos-Martin, F., Onaindia, M., Lopez-Santiago, C., and Montes, C. 2012. Uncovering 
951 ecosystem service bundles through social preferences. PloS one 7(6): e38970. doi:

952 10.1371/journal.pone.0038970.

953 Marzluff, J.M., Millspaugh, J.J., Ceder, K.R., Oliver, C.D., Withey, J., McCarter, J.B., Mason,

954 C.L., and Comnick, J. 2002. Modeling changes in wildlife habitat and timber revenues in 955 response to forest management. Forest Science 48(2): 191-202.

956 Maynard, D.G., Paré, D., Thiffault, E., Lafleur, B., Hogg, K.E., and Kishchuk, B. 2014. How do 957 natural disturbances and human activities affect soils and tree nutrition and growth in the 958 Canadian boreal forest? . Environ Rev 22(2): 161-178. doi: 10.1139/er-2013-0057.

959 McCarney, G.R., Armstrong, G.W., and Adamowicz, W.L. 2008. Joint production of timber, 960 carbon, and wildlife habitat in the Canadian boreal plains. Can J Forest Res 38(6): 1478-1492. 961 doi: 10.1139/X07-246.

962 McShane, T.O., Hirsch, P.D., Trung, T.C., Songorwa, A.N., Kinzig, A., Monteferri, B., 963 Mutekanga, D., Thang, H.V., Dammert, J.L., Pulgar-Vidal, M., Welch-Devine, M., Brosius, J.P., 964 Coppolillo, P., and O'Connor, S. 2011. Hard choices: Making trade-offs between biodiversity 965 conservation and human well-being. Biological Conservation 144(3): 966-972. doi:

966 10.1016/j.biocon.2010.04.038.

967 Mendenhall, C.D., Sekercioglu, C.H., Brenes, F.O., Ehrlich, P.R., and Daily, G.C. 2011.

968 Predictive model for sustaining biodiversity in tropical countryside. Proc Natl Acad Sci U S A 969 108(39): 16313-16316. doi: 10.1073/pnas.1111687108.

970 Mendoza, G.A., and Martins, H. 2006. Multi-criteria decision analysis in natural resource 971 management: A critical review of methods and new modelling paradigms. Forest Ecology and 972 Management 230(1-3): 1-22. doi: 10.1016/j.foreco.2006.03.023. 
973 Mendoza, G.A., Önal, H., and Soetjipto, W. 2000. Optimising tree diversity and economic 974 returns from managed mixed forests in Kalimantan, Indonesia. Journal of Tropical Forest 975 Science: 298-319.

976 Millennium Ecosystem Assessment. 2005. Millennium ecosystem assessment: Ecosystems and 977 human well-being. Island Press Washington, DC.

978 Monkkonen, M., Juutinen, A., Mazziotta, A., Miettinen, K., Podkopaev, D., Reunanen, P., 979 Salminen, H., and Tikkanen, O.P. 2014. Spatially dynamic forest management to sustain 980 biodiversity and economic returns. J Environ Manage 134: 80-89. doi:

$981 \quad$ 10.1016/j.jenvman.2013.12.021.

982 Montgomery, C. 1995. Economic-Analysis of the Spatial Dimensions of Species Preservation 983 the Distribution of Northern Spotted Owl Habitat. Forest Science 41(1): 67-83.

984 Montgomery, C.A., Brown, G.M., and Adams, D.M. 1994. The Marginal Cost of Species

985 Preservation - the Northern Spotted Owl. Journal of Environmental Economics and Management 986 26(2): 111-128. doi: 10.1006/jeem.1994.1007.

987 Mulia, R., Widayati, A., Suyanto, Agung, P., and Zulkarnain, M.T. 2014. Low carbon emission 988 development strategies for Jambi, Indonesia: simulation and trade-off analysis using the 989 FALLOW model. Mitigation and Adaptation Strategies for Global Change 19(6): 773-788. doi: $990 \quad 10.1007 / \mathrm{s} 11027-013-9485-8$.

991 Muradian, R., Arsel, M., Pellegrini, L., Adaman, F., Aguilar, B., Agarwal, B., Corbera, E., de 992 Blas, D.E., Farley, J., Froger, G., Garcia-Frapolli, E., Gomez-Baggethun, E., Gowdy, J., Kosoy, 993 N., Le Coq, J.F., Leroy, P., May, P., Meral, P., Mibielli, P., Norgaard, R., Ozkaynak, B., Pascual, 994 U., Pengue, W., Perez, M., Pesche, D., Pirard, R., Ramos-Martin, J., Rival, L., Saenz, F., Van 995 Hecken, G., Vatn, A., Vira, B., and Urama, K. 2013. Payments for ecosystem services and the 
996 fatal attraction of win-win solutions. Conservation Letters 6(4): 274-279. doi: 10.1111/j.1755997 263X.2012.00309.x.

998 Murray, A.T., and Church, R.L. 1995. Heuristic Solution Approaches to Operational Forest 999 Planning Problems. Or Spektrum 17(2-3): 193-203. doi: 10.1007/BF01719265.

1000 Naeem, S., and Wright, J.P. 2003. Disentangling biodiversity effects on ecosystem functioning: 1001 deriving solutions to a seemingly insurmountable problem. Ecology Letters 6(6): 567-579. doi: 1002 10.1046/j.1461-0248.2003.00471.x.

1003 Naidoo, R., and Ricketts, T.H. 2006. Mapping the economic costs and benefits of conservation. 1004 PLoS Biol 4(11): e360. doi: 10.1371/journal.pbio.0040360.

1005 Nalle, D.J., Montgomery, C.A., Arthur, J.L., Polasky, S., and Schumaker, N.H. 2004. Modeling 1006 joint production of wildlife and timber. Journal of Environmental Economics and Management 1007 48(3): 997-1017. doi: 10.1016/j.jeem.2004.01.001.

1008 Nelson, E., Mendoza, G., Regetz, J., Polasky, S., Tallis, H., Cameron, D.R., Chan, K.M.A., 1009 Daily, G.C., Goldstein, J., Kareiva, P.M., Lonsdorf, E., Naidoo, R., Ricketts, T.H., and Shaw, 1010 M.R. 2009. Modeling multiple ecosystem services, biodiversity conservation, commodity 1011 production, and tradeoffs at landscape scales. Frontiers in Ecology and the Environment 7(1): 41012 11. doi: $10.1890 / 080023$.

1013 Nelson, E., Polasky, S., Lewis, D.J., Plantinga, A.J., Lonsdorf, E., White, D., Bael, D., and 1014 Lawler, J.J. 2008. Efficiency of incentives to jointly increase carbon sequestration and species 1015 conservation on a landscape. Proc Natl Acad Sci U S A 105(28): 9471-9476. doi:

1016 10.1073/pnas.0706178105. 
1017 Ohman, K., Edenius, L., and Mikusinski, G. 2011. Optimizing spatial habitat suitability and 1018 timber revenue in long-term forest planning. Can J Forest Res 41(3): 543-551. doi: 10.1139/X101019232.

1020 Olschewski, R., and Benitez, P.C. 2010. Optimizing joint production of timber and carbon 1021 sequestration of afforestation projects. Journal of Forest Economics 16(1): 1-10. doi:

$1022 \quad 10.1016 /$ j.jfe.2009.03.002.

1023 Olschewski, R., Klein, A.M., and Tscharntke, T. 2010. Economic trade-offs between carbon 1024 sequestration, timber production, and crop pollination in tropical forested landscapes. Ecological 1025 Complexity 7(3): 314-319. doi: 10.1016/j.ecocom.2010.01.002.

1026 Onal, H. 1997. Trade-off between structural diversity and economic objectives in forest 1027 management. American Journal of Agricultural Economics 79(3): 1001-1012. doi:

$1028 \quad 10.2307 / 1244439$.

1029 Parkins, J.R., and MacKendrick, N.A. 2007. Assessing community vulnerability: A study of the 1030 mountain pine beetle outbreak in British Columbia, Canada. Global Environmental Change1031 Human and Policy Dimensions 17(3-4): 460-471. doi: 10.1016/j.gloenvcha.2007.01.003.

1032 Perfecto, I., Vandermeer, J., Mas, A., and Pinto, L.S. 2005. Biodiversity, yield, and shade coffee 1033 certification. Ecological Economics 54(4): 435-446. doi: 10.1016/j.ecolecon.2004.10.009.

1034 Polasky, S., Nelson, E., Camm, J., Csuti, B., Fackler, P., Lonsdorf, E., Montgomery, C., White, 1035 D., Arthur, J., Garber-Yonts, B., Haight, R., Kagan, J., Starfield, A., and Tobalske, C. 2008.

1036 Where to put things? Spatial land management to sustain biodiversity and economic returns.

1037 Biological Conservation 141(6): 1505-1524. doi: 10.1016/j.biocon.2008.03.022. 
1038 Polasky, S., Nelson, E., Lonsdorf, E., Fackler, P., and Starfield, A. 2005. Conserving Species in a 1039 Working Landscape: Land Use with Biological and Economic Objectives. Ecological 1040 Applications 15(4): 1387-1401. doi: 10.1890/03-5423.

1041 Polasky, S., Nelson, E., Pennington, D., and Johnson, K.A. 2011. The Impact of Land-Use 1042 Change on Ecosystem Services, Biodiversity and Returns to Landowners: A Case Study in the 1043 State of Minnesota. Environmental \& Resource Economics 48(2): 219-242. doi:

$1044 \quad 10.1007 / \mathrm{s} 10640-010-9407-0$.

1045 Prato, T. 2009. Evaluating Tradeoffs Between Economic Value and Wildlife Habitat Suitability 1046 in Buffer Zones for Protected Areas in the Northern Rocky Mountains, USA. Mountain Research 1047 and Development 29(1): 46-58. doi: 10.1659/mrd.992.

1048 Price, D.T., Alfaro, R.I., Brown, K.J., Flannigan, M.D., Fleming, R.A., Hogg, E.H., Girardin, 1049 M.P., Lakusta, T., Johnston, M., McKenney, D.W., Pedlar, J.H., Stratton, T., Sturrock, R.N., 1050 Thompson, I.D., Trofymow, J.A., and Venier, L.A. 2013. Anticipating the consequences of 1051 climate change for Canada's boreal forest ecosystems. Environ Rev 21(4): 322-365. doi:

$1052 \quad 10.1139 / \mathrm{er}-2013-0042$.

1053 Priess, J.A., Mimler, M., Klein, A.M., Schwarze, S., Tscharntke, T., and Steffan-Dewenter, I. 1054 2007. Linking deforestation scenarios to pollination services and economic returns in coffee 1055 agroforestry systems. Ecological applications : a publication of the Ecological Society of 1056 America 17(2): 407-417. doi: 10.1890/05-1795.

1057 Probert, W.J.M., Hauser, C.E., McDonald-Madden, E., Runge, M.C., Baxter, P.W.J., and 1058 Possingham, H.P. 2011. Managing and learning with multiple models: Objectives and 1059 optimization algorithms. Biological Conservation 144(4): 1237-1245. doi:

$1060 \quad$ 10.1016/j.biocon.2010.07.031. 
1061 Purvis, A., and Hector, A. 2000. Getting the measure of biodiversity. Nature 405(6783): 2121062 219. doi: $10.1038 / 35012221$.

1063 Pussinen, A., Karjalainen, T., Makipaa, R., Valsta, L., and Kellomaki, S. 2002. Forest carbon 1064 sequestration and harvests in Scots pine stand under different climate and nitrogen deposition 1065 scenarios. Forest Ecology and Management 158(1-3): 103-115. doi: 10.1016/S0378$1066 \quad 1127(00) 00675-7$.

1067 Pyorala, P., Peltola, H., Strandman, H., Antti, K., Antti, A., Jylha, K., and Kellomaki, S. 2014. 1068 Effects of Management on Economic Profitability of Forest Biomass Production and Carbon 1069 Neutrality of Bioenergy Use in Norway Spruce Stands Under the Changing Climate. Bioenergy 1070 Research 7(1): 279-294. doi: 10.1007/s12155-013-9372-x.

1071 Raudsepp-Hearne, C., Peterson, G.D., and Bennett, E.M. 2010. Ecosystem service bundles for 1072 analyzing tradeoffs in diverse landscapes. Proc Natl Acad Sci U S A 107(11): 5242-5247. doi: 1073 10.1073/pnas.0907284107.

1074 Redford, K.H., and Adams, W.M. 2009. Payment for ecosystem services and the challenge of 1075 saving nature. Conservation biology : the journal of the Society for Conservation Biology 23(4): 1076 785-787. doi: 10.1111/j.1523-1739.2009.01271.x.

1077 Ricketts, T.H., Daily, G.C., Ehrlich, P.R., and Michener, C.D. 2004. Economic value of tropical 1078 forest to coffee production. Proc Natl Acad Sci U S A 101(34): 12579-12582. doi:

1079 10.1073/pnas.0405147101.

1080 Rodriguez, J.P., Beard, T.D., Bennett, E.M., Cumming, G.S., Cork, S.J., Agard, J., Dobson, A.P., 1081 and Peterson, G.D. 2006. Trade-offs across space, time, and ecosystem services. Ecology and 1082 Society 11(1): 28 . 
1083 Rohweder, M.R., McKetta, C.W., and Riggs, R.A. 2000. Economic and biological compatibility 1084 of timber and wildlife production: an illustrative use of production possibilities frontier. Wildlife 1085 Society Bulletin 28(2): 435-447. doi: 10.2307/3783701.

1086 Rose, S.K., and Chapman, D. 2003. Timber harvest adjacency economies, hunting, species 1087 protection, and old growth value: seeking the dynamic optimum. Ecological Economics 44(2-3): 1088 325-344. doi: 10.1016/S0921-8009(02)00268-9.

1089 Saint-Arnaud, M., H. Asselin, C. Dubé, Croteau, Y., and Papatie, C. 2009. Developing Criteria 1090 and Indicators for Aboriginal Forestry: Mutual Learning through Collaborative Research. In 1091 Stevenson M.G. and D.C. Natcher (eds.). Changing the Culture of Forestry in Canada. pp. 851092 105. . CCI Press and Sustainable Forest Management Network, Edmonton, AB.

1093 Sala, O.E., Chapin, F.S., 3rd, Armesto, J.J., Berlow, E., Bloomfield, J., Dirzo, R., Huber1094 Sanwald, E., Huenneke, L.F., Jackson, R.B., Kinzig, A., Leemans, R., Lodge, D.M., Mooney, 1095 H.A., Oesterheld, M., Poff, N.L., Sykes, M.T., Walker, B.H., Walker, M., and Wall, D.H. 2000. 1096 Global biodiversity scenarios for the year 2100. Science 287(5459): 1770-1774. doi: $1097 \quad 10.1126 /$ science.287.5459.1770.

1098 Schwenk, W.S., Donovan, T.M., Keeton, W.S., and Nunery, J.S. 2012. Carbon storage, timber 1099 production, and biodiversity: comparing ecosystem services with multi-criteria decision analysis. 1100 Ecological applications : a publication of the Ecological Society of America 22(5): 1612-1627. 1101 Seely, B., Nelson, J., Wells, R., Peter, B., Meitner, M., Anderson, A., Harshaw, H., Sheppard, S., 1102 Bunnell, F.L., Kimmins, H., and Harrison, D. 2004. The application of a hierarchical, decision1103 support system to evaluate multi-objective forest management strategies: a case study in 1104 northeastern British Columbia, Canada. Forest Ecology and Management 199(2-3): 283-305. 1105 doi: 10.1016/j.foreco.2004.05.048. 
1106 Seidl, R., Rammer, W., Jager, D., Currie, W.S., and Lexer, M.J. 2007. Assessing trade-offs

1107 between carbon sequestration and timber production within a framework of multi-purpose

1108 forestry in Austria. Forest Ecology and Management 248(1-2): 64-79. doi:

$1109 \quad$ 10.1016/j.foreco.2007.02.035.

1110 Seidl, R., Rammer, W., Jager, D., and Lexer, M.J. 2008. Impact of bark beetle (Ips typographus

1111 L.) disturbance on timber production and carbon sequestration in different management

1112 strategies under climate change. Forest Ecology and Management 256(3): 209-220. doi:

1113 10.1016/j.foreco.2008.04.002.

1114 Seppelt, R., Dormann, C.F., Eppink, F.V., Lautenbach, S., and Schmidt, S. 2011. A quantitative

1115 review of ecosystem service studies: approaches, shortcomings and the road ahead. Journal of

1116 Applied Ecology 48(3): 630-636. doi: 10.1111/j.1365-2664.2010.01952.x.

1117 Seppelt, R., Lautenbach, S., and Volk, M. 2013. Identifying trade-offs between ecosystem

1118 services, land use, and biodiversity: a plea for combining scenario analysis and optimization on

1119 different spatial scales. Current Opinion in Environmental Sustainability 5(5): 458-463. doi:

$1120 \quad 10.1016 /$ j.cosust.2013.05.002.

1121 Spring, D.A., Kennedy, J.O.S., and Mac Nally, R. 2005. Optimal management of a forested

1122 catchment providing timber and carbon sequestration benefits: Climate change effects. Global

1123 Environmental Change-Human and Policy Dimensions 15(3): 281-292. doi:

1124 10.1016/j.gloenvcha.2005.04.002.

1125 Steffan-Dewenter, I., Kessler, M., Barkmann, J., Bos, M.M., Buchori, D., Erasmi, S., Faust, H.,

1126 Gerold, G., Glenk, K., Gradstein, S.R., Guhardja, E., Harteveld, M., Hertel, D., Hohn, P.,

1127 Kappas, M., Kohler, S., Leuschner, C., Maertens, M., Marggraf, R., Migge-Kleian, S., Mogea, J.,

1128 Pitopang, R., Schaefer, M., Schwarze, S., Sporn, S.G., Steingrebe, A., Tjitrosoedirdjo, S.S., 
1129 Tjitrosoemito, S., Twele, A., Weber, R., Woltmann, L., Zeller, M., and Tscharntke, T. 2007.

1130 Tradeoffs between income, biodiversity, and ecosystem functioning during tropical rainforest

1131 conversion and agroforestry intensification. Proc Natl Acad Sci U S A 104(12): 4973-4978. doi:

$1132 \quad 10.1073 /$ pnas.0608409104.

1133 Steffen, W., Richardson, K., Rockstrom, J., Cornell, S.E., Fetzer, I., Bennett, E.M., Biggs, R.,

1134 Carpenter, S.R., de Vries, W., de Wit, C.A., Folke, C., Gerten, D., Heinke, J., Mace, G.M.,

1135 Persson, L.M., Ramanathan, V., Reyers, B., and Sorlin, S. 2015. Sustainability. Planetary

1136 boundaries: guiding human development on a changing planet. Science 347(6223): 1259855.

1137 doi: $10.1126 /$ science. 1259855.

1138 Stevenson, M.G., and Webb, G. (eds). 2003. Just another stakeholder? First Nations and

1139 sustainable forest management in Canada's boreal forest in (eds.) Burton, P. J.; Messier, C.;

1140 Smith, D. W.; Adamowicz, W. L., Towards sustainable management of the boreal forest. pp. 65-

1141 112. NRC Research Press.

1142 Stirn, L.Z. 2006. Integrating the fuzzy analytic hierarchy process with dynamic programming

1143 approach for determining the optimal forest management decisions. Ecological Modelling 194(1-

1144 3): 296-305. doi: 10.1016/j.ecolmodel.2005.10.023.

1145 Stocks, B.J., Fosberg, M.A., Lynham, T.J., Mearns, L., Wotton, B.M., Yang, Q., Jin, J.Z.,

1146 Lawrence, K., Hartley, G.R., Mason, J.A., and McKenney, D.W. 1998. Climate change and

1147 forest fire potential in Russian and Canadian boreal forests. Climatic Change 38(1): 1-13. doi:

$1148 \quad 10.1023 / \mathrm{A}: 1005306001055$.

1149 Thomas, C.D., Cameron, A., Green, R.E., Bakkenes, M., Beaumont, L.J., Collingham, Y.C.,

1150 Erasmus, B.F., De Siqueira, M.F., Grainger, A., Hannah, L., Hughes, L., Huntley, B., Van

1151 Jaarsveld, A.S., Midgley, G.F., Miles, L., Ortega-Huerta, M.A., Peterson, A.T., Phillips, O.L., 
1152 and Williams, S.E. 2004. Extinction risk from climate change. Nature 427(6970): 145-148. doi:

$115310.1038 /$ nature02121.

1154 Thompson, D.G., and Pitt, D.G. 2003. A review of Canadian forest vegetation management 1155 research and practice. Ann Forest Sci 60(7): 559-572. doi: 10.1051/forest:2003060.

1156 Tikkanen, O.P., Heinonen, T., Kouki, J., and Matero, J. 2007. Habitat suitability models of 1157 saproxylic red-listed boreal forest species in long-term matrix management: Cost-effective 1158 measures for multi-species conservation. Biological Conservation 140(3-4): 359-372. doi:

1159 10.1016/j.biocon.2007.08.020.

1160 Trivino, M., Juutinen, A., Mazziotta, A., Miettinen, K., Podkopaev, D., Reunanen, P., and 1161 Monkkonen, M. 2015. Managing a boreal forest landscape for providing timber, storing and 1162 sequestering carbon. Ecosystem Services 14: 179-189. doi: 10.1016/j.ecoser.2015.02.003. 1163 Turner, K.G., Anderson, S., Gonzales-Chang, M., Costanza, R., Courville, S., Dalgaard, T., 1164 Dominati, E., Kubiszewski, I., Ogilvy, S., Porfirio, L., Ratna, N., Sandhu, H., Sutton, P.C., 1165 Svenning, J.C., Turner, G.M., Varennes, Y.D., Voinov, A., and Wratten, S. 2016. A review of 1166 methods, data, and models to assess changes in the value of ecosystem services from land 1167 degradation and restoration. Ecological Modelling 319: 190-207. doi:

$1168 \quad$ 10.1016/j.ecolmodel.2015.07.017.

1169 van Noordwijk, M. 2002. Scaling trade-offs between crop productivity, carbon stocks and 1170 biodiversity in shifting cultivation landscape mosaics: the FALLOW model. Ecological

1171 Modelling 149(1-2): 113-126. doi: 10.1016/s0304-3800(01)00518-x.

1172 van Noordwijk, M., Suyamto, D.A., Lusiana, B., Ekadinata, A., and Hairiah, K. 2008.

1173 Facilitating agroforestation of landscapes for sustainable benefits: Tradeoffs between carbon 
1174 stocks and local development benefits in Indonesia according to the FALLOW model.

1175 Agriculture, Ecosystems \& Environment 126(1-2): 98-112. doi: 10.1016/j.agee.2008.01.016.

1176 Venier, L.A., Thompson, I.D., Fleming, R., Malcolm, J., Aubin, I., Trofymow, J.A., Langor, D.,

1177 Sturrock, R., Patry, C., Outerbridge, R.O., Holmes, S.B., Haeussler, S., De Grandpre, L., Chen,

1178 H.Y.H., Bayne, E., Arsenault, A., and Brandt, J.P. 2014. Effects of natural resource development

1179 on the terrestrial biodiversity of Canadian boreal forests. Environ Rev 22(4): 457-490. doi:

$1180 \quad 10.1139 / \mathrm{er}-2013-0075$.

1181 Vidal-Legaz, B., Martinez-Fernandez, J., Picon, A.S., and Pugnaire, F.I. 2013. Trade-offs

1182 between maintenance of ecosystem services and socio-economic development in rural

1183 mountainous communities in southern Spain: a dynamic simulation approach. J Environ Manage

1184 131: 280-297. doi: 10.1016/j.jenvman.2013.09.036.

1185 Viglizzo, E.F., and Frank, F.C. 2006. Land-use options for Del Plata Basin in South America:

1186 Tradeoffs analysis based on ecosystem service provision. Ecological Economics 57(1): 140-151.

1187 doi: 10.1016/j.ecolecon.2005.03.025.

1188 Vitousek, P.M. 1997. Human Domination of Earth's Ecosystems. Science 277(5325): 494-499.

1189 doi: 10.1126/science.277.5325.494.

1190 Wagner, R.G., Little, K.M., Richardson, B., and McNabb, K. 2006. The role of vegetation

1191 management for enhancing productivity of the world's forests. Forestry 79(1): 57-79. doi:

$1192 \quad 10.1093 /$ forestry/cpi057.

1193 Wainger, L., and Mazzotta, M. 2011. Realizing the potential of ecosystem services: a framework

1194 for relating ecological changes to economic benefits. Environ Manage 48(4): 710-733. doi:

$1195 \quad 10.1007 / \mathrm{s} 00267-011-9726-0$. 
1196 Webster, K.L., Beall, F.D., Creed, I.F., and Kreutzweiser, D.P. 2015. Impacts and prognosis of 1197 natural resource development on water and wetlands in Canada's boreal zone. Environ Rev 1198 23(1): 78-131. doi: 10.1139/er-2014-0063.

1199 Williams, P.H., Moore, J.L., Toham, A.K., Brooks, T.M., Strand, H., D'Amico, J., Wisz, M., 1200 Burgess, N.D., Balmford, A., and Rahbek, C. 2003. Integrating biodiversity priorities with 1201 conflicting socio-economic values in the Guinean-Congolian forest region. Biodiversity and 1202 Conservation 12(6): 1297-1320. doi: 10.1023/A:1023092100942.

1203 Williamson, T.B., Colombo, S., Duinker, P., Gray, P., Hennessey, R., Houle, D., Johnston, M., 1204 Ogden, A., and Spittlehouse, D. 2009. Climate change and Canada's forests: from impacts to 1205 adaptation. Natural Resources Canada, Canadian Forest Service, Northern Forestry Centre, 1206 Edmonton, Alberta. pp. 1-61.

1207 Winston, W.L., and Goldberg, J.B. 2004. Operations research: applications and algorithms.

1208 Duxbury press Boston, USA. pp. 1-2.

1209 Wolsey, L.A. 1998. Integer programming. Wiley New York, USA.

1210 Wood, S.L.R., Rhemtulla, J.M., and Coomes, O.T. 2016. Intensification of tropical fallow-based 1211 agriculture: Trading-off ecosystem services for economic gain in shifting cultivation landscapes?

1212 Agriculture, Ecosystems \& Environment 215: 47-56. doi: 10.1016/j.agee.2015.09.005.

1213 Wunder, S. 2008. Payments for environmental services and the poor: concepts and preliminary 1214 evidence. Environment and Development Economics 13(3): 279-297. doi:

$1215 \quad 10.1017 / \mathrm{S} 1355770 x 08004282$.

1216 Yi, Z.F., Cannon, C.H., Chen, J., Ye, C.X., and Swetnam, R.D. 2014. Developing indicators of 1217 economic value and biodiversity loss for rubber plantations in Xishuangbanna, southwest China: 
1218 A case study from Menglun township. Ecological Indicators 36: 788-797. doi:

$1219 \quad$ 10.1016/j.ecolind.2013.03.016.

1220 Yousefpour, R., and Hanewinkel, M. 2009. Modelling of forest conversion planning with an

1221 adaptive simulation-optimization approach and simultaneous consideration of the values of

1222 timber, carbon and biodiversity. Ecological Economics 68(6): 1711-1722. doi:

$1223 \quad 10.1016 / \mathrm{j}$. ecolecon.2008.12.009.

1224 Zhang, D., and Pearse, P.H. 2012. Forest economics. UBC Press, Vancouver, Canada. pp. 3-9.

1225 Zhang, Y., Chen, H.Y.H., and Reich, P.B. 2012. Forest productivity increases with evenness,

1226 species richness and trait variation: a global meta-analysis. Journal of Ecology 100(3): 742-749.

1227 doi: 10.1111/j.1365-2745.2011.01944.x.

1228 Zhou, W.C., and Gong, P.C. 2005. Multiple-use tradeoffs in Swedish mountain region forests.

1229 Forest Policy Econ. 7(1): 39-52. doi: 10.1016/S1389-9341(03)00010-8.

1230 Zubizarreta-Gerendiain, A., Pukkala, T., and Peltola, H. 2016. Effects of wood harvesting and

1231 utilisation policies on the carbon balance of forestry under changing climate: a Finnish case

1232 study. Forest Policy Econ. 62: 168-176. doi: 10.1016/j.forpol.2015.08.007. 


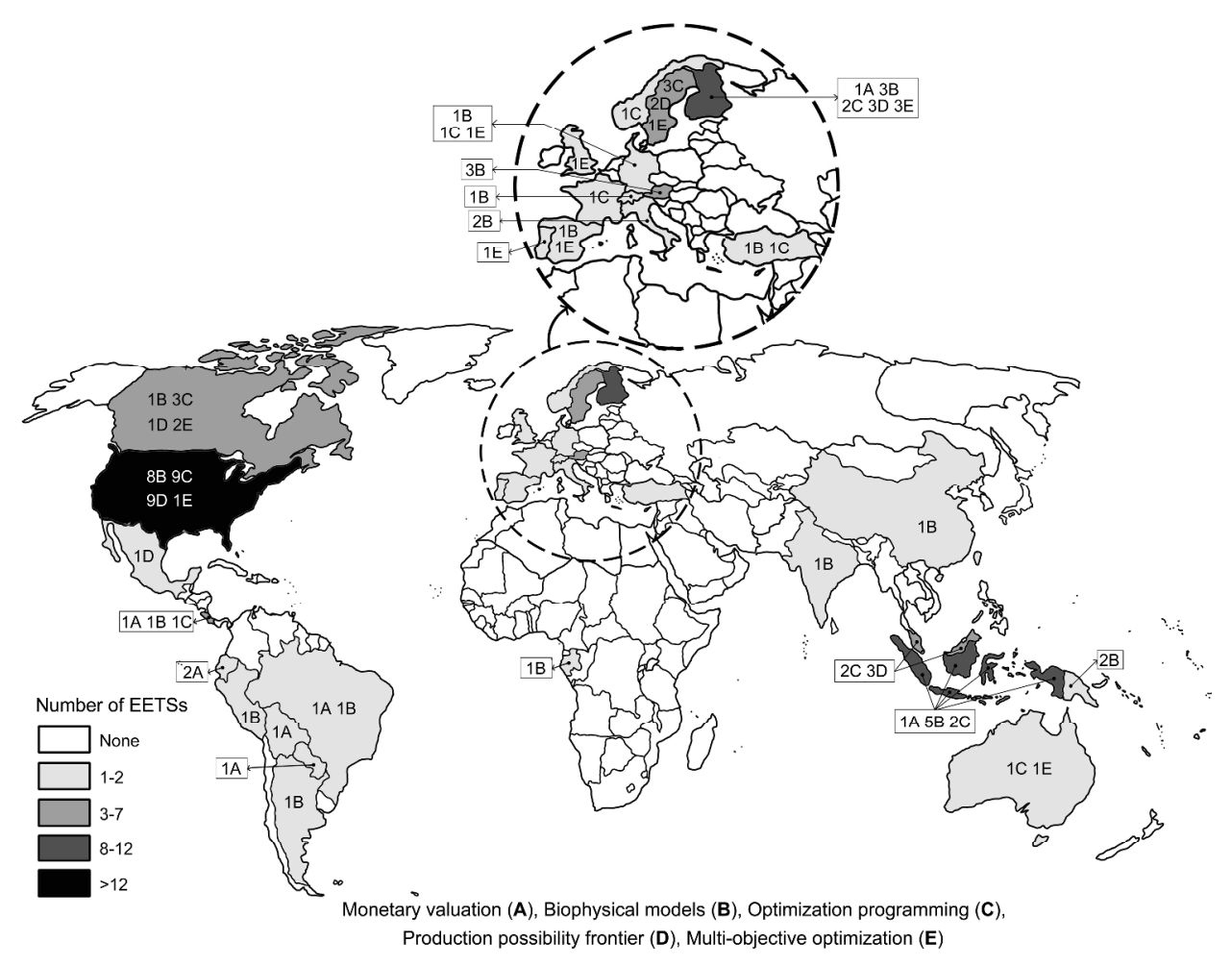

Fig. 1. Geographical distribution of economic and ecological trade-off studies (EETSs). $579 \times 440 \mathrm{~mm}(300 \times 300 \mathrm{DPI})$ 


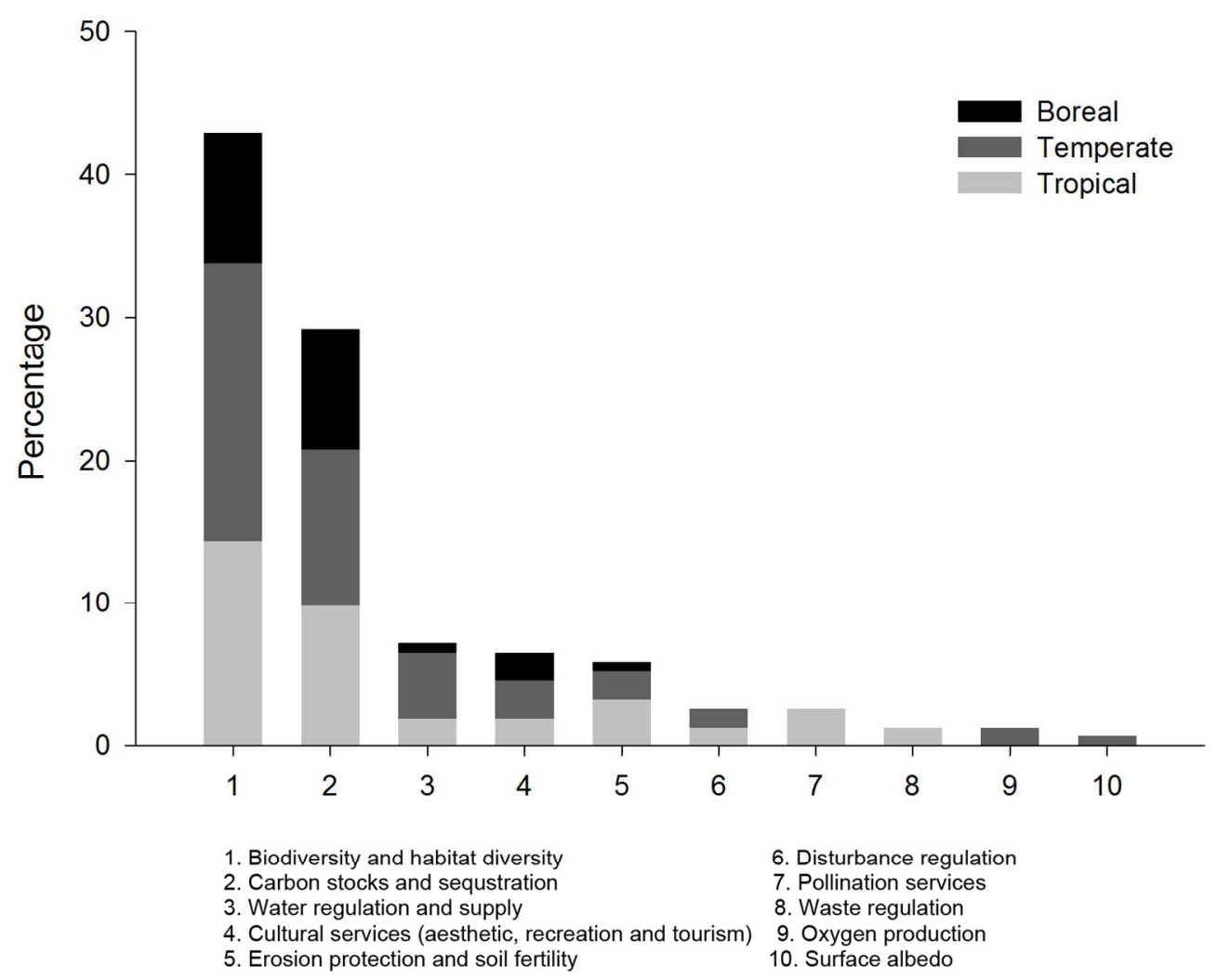

Fig. 2. Percentage of ecological functions and ecosystem services involved in the economic and ecological trade-off studies.

$135 \times 115 \mathrm{~mm}(300 \times 300$ DPI $)$ 


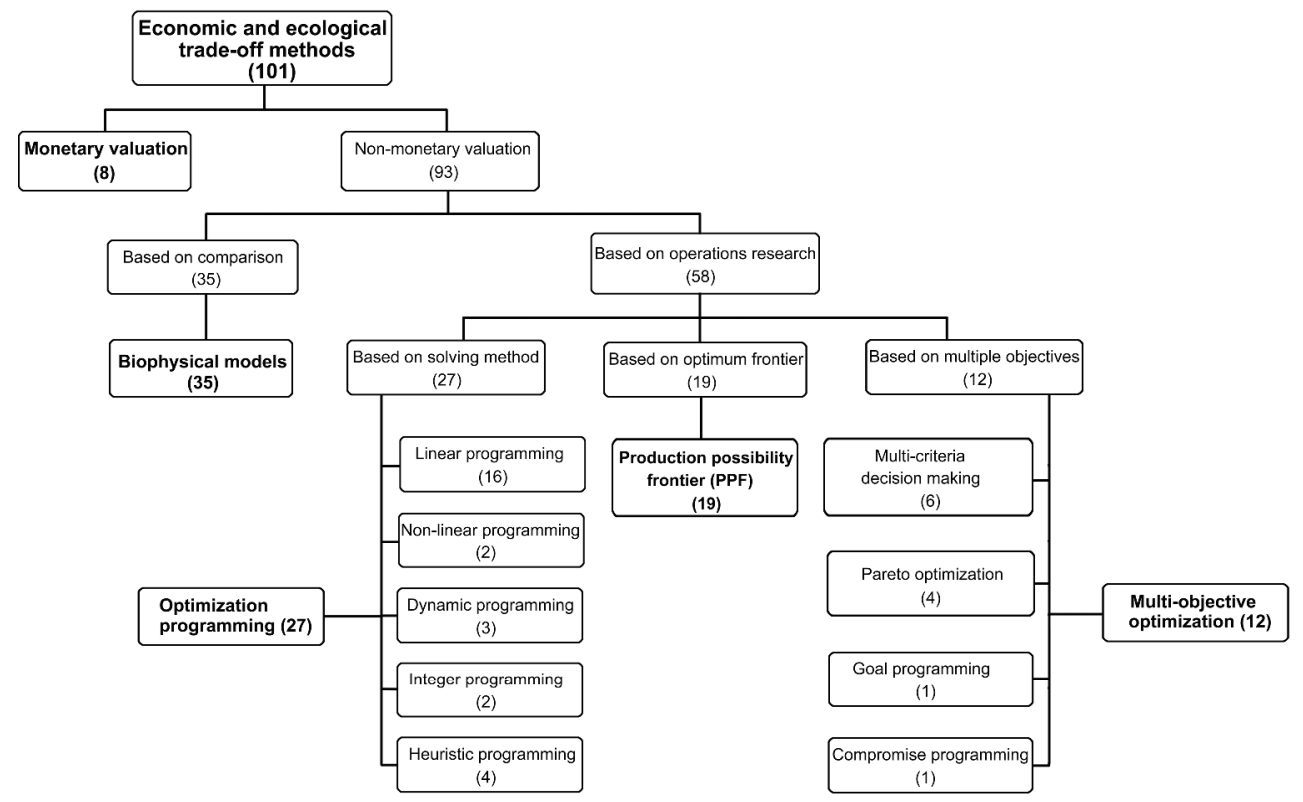

Fig. 3. Classification of primary economic and ecological trade-off methods. $663 \times 420 \mathrm{~mm}(300 \times 300$ DPI $)$ 
Table 1. Comparison of economic and ecological trade-off studies in boreal forests.

\begin{tabular}{|c|c|c|c|c|}
\hline $\begin{array}{l}\text { Methods } \\
\text { (Number of } \\
\text { studies) }\end{array}$ & $\begin{array}{l}\text { Countries } \\
\text { (Number of } \\
\text { studies) }\end{array}$ & Economic objectives & Ecological objectives & $\begin{array}{l}\text { Techniques (Number of } \\
\text { trade-off objectives) }\end{array}$ \\
\hline $\begin{array}{l}\text { Monetary } \\
\text { valuation (1) }\end{array}$ & Finland (1) & Timber production & Cultural services (tourism) & Monetary valuation (2) \\
\hline \multirow[t]{2}{*}{$\begin{array}{l}\text { Biophysical models } \\
\text { (4) }\end{array}$} & Finland (3) & $\begin{array}{l}\text { Net returns or } \\
\text { biomass production }\end{array}$ & Carbon stocks or sequestration & Biophysical models (2) \\
\hline & Canada (1) & $\begin{array}{l}\text { Maple syrup } \\
\text { production }\end{array}$ & $\begin{array}{l}\text { Cultural services, carbon } \\
\text { sequestration, soil fertility }\end{array}$ & Biophysical models (multiple) \\
\hline \multirow[t]{4}{*}{$\begin{array}{l}\text { Optimization } \\
\text { programming (9) }\end{array}$} & Sweden (3) & $\begin{array}{l}\text { Timber revenue or } \\
\text { production }\end{array}$ & $\begin{array}{l}\text { Biodiversity, carbon } \\
\text { sequestration }\end{array}$ & $\begin{array}{l}\text { Linear programming }(2) \text {, } \\
\text { mixed-integer programming } \\
(2)\end{array}$ \\
\hline & Canada (3) & Net returns & $\begin{array}{l}\text { Carbon stocks or sequestration, } \\
\text { structural diversity }\end{array}$ & $\begin{array}{l}\text { Linear programming }(2) \text {, non- } \\
\text { linear programming }(2)\end{array}$ \\
\hline & Finland (2) & Net returns & $\begin{array}{l}\text { Carbon balance, biodiversity } \\
\text { conservation goal }\end{array}$ & Linear programming (2) \\
\hline & Norway (1) & Timber production & Carbon sequestration & Linear programming (2) \\
\hline \multirow{3}{*}{$\begin{array}{l}\text { Production } \\
\text { possibility frontier } \\
(\mathrm{PPF})(6)\end{array}$} & Finland (3) & Timber production & $\begin{array}{l}\text { Habitat suitability or } \\
\text { biodiversity }\end{array}$ & PPF (2) \\
\hline & Sweden (2) & Timber production & Biodiversity & PPF (2) \\
\hline & Canada (1) & Timber revenue & Biodiversity & PPF (2) \\
\hline \multirow[t]{3}{*}{$\begin{array}{l}\text { Multi-objective } \\
\text { optimization (6) }\end{array}$} & Finland (3) & Timber production & $\begin{array}{l}\text { Carbon stocks or sequestration, } \\
\text { biodiversity }\end{array}$ & $\begin{array}{l}\text { Pareto optimization } \\
\text { (multiple/2), multi-criteria } \\
\text { decision analysis ( } 3 \text { ) }\end{array}$ \\
\hline & Canada (2) & Net returns & $\begin{array}{l}\text { Carbon uptake, structural } \\
\text { diversity, biodiversity, carbon } \\
\text { storage }\end{array}$ & $\begin{array}{l}\text { Compromise programming } \\
\text { (3), multi-criteria decision } \\
\text { analysis (3) }\end{array}$ \\
\hline & Sweden (1) & $\begin{array}{l}\text { Timber production } \\
\text { and revenue }\end{array}$ & $\begin{array}{l}\text { Biodiversity, recreation, reindeer } \\
\text { grazing }\end{array}$ & Pareto optimization (4) \\
\hline
\end{tabular}


Table 2. Primary ecological functions and ecosystem services relevant to the boreal forests.

\begin{tabular}{|c|c|c|c|}
\hline & Services & Functions & Example of services \\
\hline \multirow{7}{*}{$\begin{array}{l}\text { Production } \\
\text { Functions and } \\
\text { Provisioning } \\
\text { Services }\end{array}$} & \multicolumn{3}{|c|}{$\begin{array}{l}\text { Provisioning of natural resources, raw materials or energy outputs } \\
\text { from boreal forests }\end{array}$} \\
\hline & Raw materials & $\begin{array}{l}\text { Species or abiotic components with potential } \\
\text { use for building and manufacturing }\end{array}$ & $\begin{array}{l}\text { Lumber, plant fibers, bioenergy, non- } \\
\text { timber products such as mushrooms and } \\
\text { berries, skins, oils, subsistence values for } \\
\text { Indigenous communities and households }\end{array}$ \\
\hline & Water supply & $\begin{array}{l}\text { Filtering, retention, and storage of fresh } \\
\text { water from wetland, surface waters, and } \\
\text { groundwater }\end{array}$ & $\begin{array}{l}\text { Provision of fresh water for drinking, } \\
\text { irrigation, and transportation }\end{array}$ \\
\hline & Food & $\begin{array}{l}\text { Provisioning of edible plants and animals for } \\
\text { human consumption }\end{array}$ & $\begin{array}{l}\text { Gathering edible plants and hunting } \\
\text { animals }\end{array}$ \\
\hline & Genetic resources & $\begin{array}{l}\text { Presence of species with useful genetic } \\
\text { materials }\end{array}$ & $\begin{array}{l}\text { Genes to improve tree resistance to } \\
\text { pathogens and pests }\end{array}$ \\
\hline & Medicinal resources & $\begin{array}{l}\text { Species or abiotic components with } \\
\text { potentially use in drugs and pharmaceuticals }\end{array}$ & $\begin{array}{l}\text { Balsam fir, sub-alpine fir, box elder, black } \\
\text { maple, moosewood, striped maple, red } \\
\text { maple, silver maple, mountain maple, } \\
\text { milfoil, boreal yarrow, Siberian yarrow, } \\
\text { Alaska wild rhubarb, American sweetflag, } \\
\text { white baneberry, cohosh root }\end{array}$ \\
\hline & Ornamental resource & $\begin{array}{l}\text { Resources for handicraft, worship, } \\
\text { decoration, and souvenirs }\end{array}$ & $\begin{array}{l}\text { Feathers or fur used in decorative costumes } \\
\text { in Indigenous communities }\end{array}$ \\
\hline Habitat & \multicolumn{3}{|c|}{ Ecological structures and functions that are } \\
\hline Functions and & \multicolumn{3}{|c|}{ essential to the delivery of other ecosystem services in boreal forests } \\
\hline & Net primary & Conversion of solar energy into biomass & Plant growth \\
\hline
\end{tabular}




\begin{tabular}{|c|c|c|c|}
\hline & production & through photosynthesis & \\
\hline & Nutrient cycling & Acquisition, storage, recycling of nutrients & Nitrogen and phosphorus cycle \\
\hline & $\begin{array}{l}\text { Biodiversity and } \\
\text { habitat }\end{array}$ & $\begin{array}{l}\text { Supporting variety and variability of life, and } \\
\text { providing breeding, feeding or residing } \\
\text { habitat for boreal species }\end{array}$ & $\begin{array}{l}\text { Plant diversity, refugium for resident and } \\
\text { migratory species, nurseries for spawning }\end{array}$ \\
\hline & $\begin{array}{l}\text { Maintenance of } \\
\text { genepool }\end{array}$ & $\begin{array}{l}\text { Maintenance of genetic diversity in boreal } \\
\text { forest }\end{array}$ & $\begin{array}{l}\text { Endemic species, threatened species (e.g., } \\
\text { caribou) }\end{array}$ \\
\hline & Hydrological cycle & Movement and storage of water & Evapotransporation, groundwater retention \\
\hline \multirow{10}{*}{$\begin{array}{l}\text { Regulation } \\
\text { Functions and } \\
\text { Regulating } \\
\text { Services }\end{array}$} & \multicolumn{3}{|c|}{$\begin{array}{l}\text { Regulation of essential ecological processes and life support systems } \\
\text { in boreal forests }\end{array}$} \\
\hline & Climate regulation & Regulation of climate processes & $\begin{array}{l}\text { Greenhouse gas production and absorption, } \\
\text { Carbon sequestration and storage }\end{array}$ \\
\hline & Gas regulation & Regulation of the atmospheric chemicals & $\mathrm{CO}_{2} / \mathrm{O}_{2}$ balance, stratospheric ozone \\
\hline & $\begin{array}{l}\text { Disturbance } \\
\text { regulation }\end{array}$ & $\begin{array}{l}\text { Dampening of environmental fluctuations } \\
\text { and disturbances }\end{array}$ & Fire, insect outbreaks \\
\hline & Biological control & $\begin{array}{l}\text { Control of pest populations and vector borne } \\
\text { diseases through the activities of predators } \\
\text { and parasites }\end{array}$ & $\begin{array}{l}\text { Predator control of prey species, natural } \\
\text { control of pests and diseases }\end{array}$ \\
\hline & Pollination & Movement of floral pollinators & $\begin{array}{l}\text { Provision of pollinators (e.g., wind, insect } \\
\text { and bird) for plants }\end{array}$ \\
\hline & Water regulation & $\begin{array}{l}\text { Regulation of hydrological flows in water } \\
\text { infiltration, storage, recharge, and discharge } \\
\text { in boreal forests }\end{array}$ & Modulation of the drought - flood cycle \\
\hline & Waste regulation & $\begin{array}{l}\text { Removal or breakdown of organic matter, } \\
\text { excess nutrients, and non-nutrient } \\
\text { compounds }\end{array}$ & Water purification, pollution detoxification \\
\hline & Nutrient regulation & $\begin{array}{l}\text { Maintenance of nutrients within acceptable } \\
\text { bounds }\end{array}$ & Regulation of eutrophication in lakes \\
\hline & $\begin{array}{l}\text { Erosion protection, } \\
\text { and maintenance of }\end{array}$ & $\begin{array}{l}\text { Erosion control of soil, and maintenance of } \\
\text { soil fertility in boreal forests }\end{array}$ & Prevention of soil loss by wind and runoff \\
\hline
\end{tabular}


soil fertility

Soil formation and Natural processes in soil formation

regeneration and regeneration

Weathering of rock, accumulation of

Air quality

Capacity of ecosystems to extract

organic material

regulation

aerosols and chemicals from the atmosphere

Capturing dust particles

Information Enhancing emotional, psychological, and cognitive benefits for

Functions and human well-beings

Cultural

Services

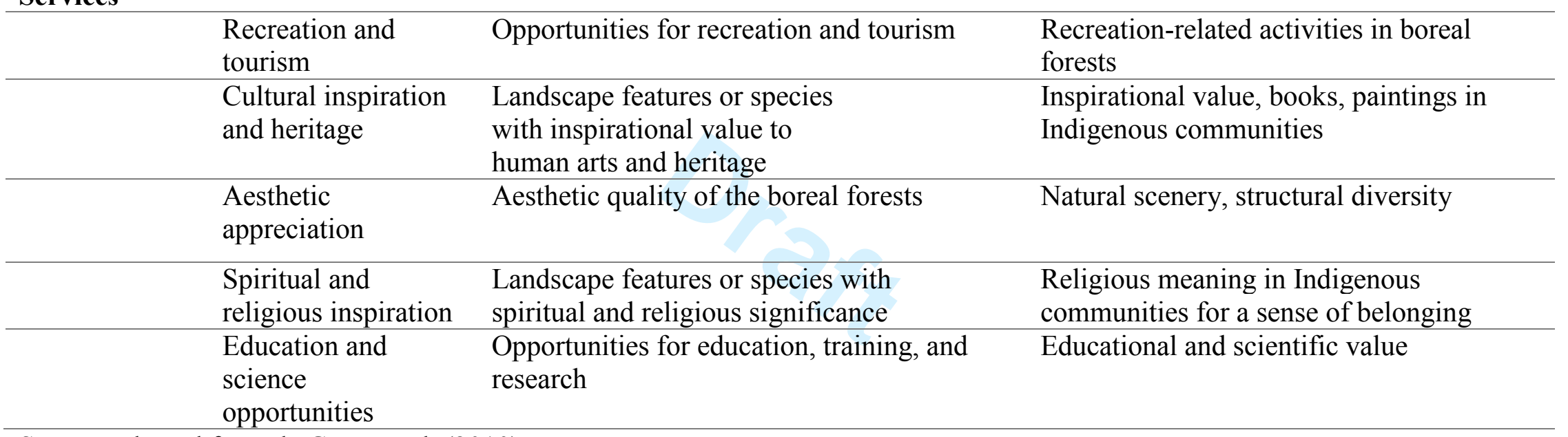

Source: adapted from de Groot et al. (2010). 